University of Nebraska - Lincoln

DigitalCommons@University of Nebraska - Lincoln

\title{
Landscape structure, groundwater dynamics, and soil water content influence soil respiration across riparian-hillslope transitions in the Tenderfoot Creek Experimental Forest, Montana
}

\author{
Vincent J. Pacific \\ Montana State University - Bozeman \\ Diego Andrés Riveros-Iregui \\ University of Nebraska - Lincoln, driveros2@unl.edu \\ Daniel L. Welsch \\ Canaan Valley Institute, Davis, WV \\ Howard E. Epstein \\ University of Virginia, hee2b@virginia.edu
}

Follow this and additional works at: https://digitalcommons.unl.edu/natrespapers

Part of the Natural Resources and Conservation Commons

Pacific, Vincent J.; Riveros-Iregui, Diego Andrés; Welsch, Daniel L.; and Epstein, Howard E., "Landscape structure, groundwater dynamics, and soil water content influence soil respiration across riparian-hillslope transitions in the Tenderfoot Creek Experimental Forest, Montana" (2011). Papers in Natural Resources. 293.

https://digitalcommons.unl.edu/natrespapers/293

This Article is brought to you for free and open access by the Natural Resources, School of at DigitalCommons@University of Nebraska - Lincoln. It has been accepted for inclusion in Papers in Natural Resources by an authorized administrator of DigitalCommons@University of Nebraska - Lincoln. 


\title{
Landscape structure, groundwater dynamics, and soil water content influence soil respiration across riparian-hillslope transitions in the Tenderfoot Creek Experimental Forest, Montana
}

\author{
Vincent J. Pacific, ${ }^{1}$ Brian L. McGlynn, ${ }^{1}$ Diego A. Riveros-Iregui, ${ }^{2}$ \\ and Daniel L. Welsch, ${ }^{3}$ Howard E. Epstein ${ }^{4}$ \\ 1. Department of Land Resources and Environmental Sciences, Montana State University, 334 Leon Johnson Hall, Bozeman, MT 59717, USA \\ 2. School of Natural Resources, University of Nebraska-Lincoln, 3310 Holdrege Street, Lincoln, NE 68583, USA \\ 3. Canaan Valley Institute, 494 Riverstone Road, Davis, WV, USA \\ 4. Department of Environmental Sciences, University of Virginia, 211 Clark Hall, Charlottesville, VA 22904, USA \\ Corresponding author - Vincent J. Pacific, Department of Land Resources and Environmental Sciences, \\ Montana State University, 334 Leon Johnson Hall, Bozeman, MT 59717, USA; email vincent.pacific@gmail.com
}

\begin{abstract}
Variability in soil respiration at various spatial and temporal scales has been the focus of much research over the last decade aimed to improve our understanding and parameterization of physical and environmental controls on this flux. However, few studies have assessed the control of landscape position and groundwater table dynamics on the spatiotemporal variability of soil respiration. We investigated growing season soil respiration in a $\sim 393$ ha subalpine watershed in Montana across eight riparianhillslope transitions that differed in slope, upslope accumulated area (UAA), aspect, and groundwater table dynamics. We collected daily-to-weekly measurements of soil water content (SWC), soil temperature, soil $\mathrm{CO}_{2}$ concentrations, surface $\mathrm{CO}_{2}$ efflux, and groundwater table depth, as well as soil C and N concentrations at 32 locations from June to August 2005. Instantaneous soil surface $\mathrm{CO}_{2}$ efflux was not significantly different within or among riparian and hillslope zones at monthly timescales. However, cumulative integration of $\mathrm{CO}_{2}$ efflux during the 83-day growing season showed that efflux in the wetter riparian zones was $~ 25 \%$ greater than in the adjacent drier hillslopes. Furthermore, greater cumulative growing season efflux occurred in areas with high UAA and gentle slopes, where groundwater tables were higher and more persistent. Our findings reveal the influence of landscape position and groundwater table dynamics on riparian versus hillslope soil $\mathrm{CO}_{2}$ efflux and the importance of time integration for assessment of soil $\mathrm{CO}_{2}$ dynamics, which is critical for landscape-scale simulation and modeling of soil $\mathrm{CO}_{2}$ efflux in complex landscapes.
\end{abstract}

Keywords: soil respiration, $\mathrm{CO}_{2}$, landscape, groundwater, riparian-hillslope, $\mathrm{C}: \mathrm{N}$ ratios, topography, SWC

\section{Introduction}

Soil respiration constitutes the largest terrestrial flux of $\mathrm{CO}_{2}$ to the atmosphere, contributing over an order of magnitude more $\mathrm{CO}_{2}$ than anthropogenic sources (Raich et al., 2002). Past research has examined the spatial variability of soil respiration across landscapes and has revealed important differences in this flux associated with spatial location. For example, significant differences in soil respiration have been found between north- and south-facing slopes in the northern hemisphere (Kang et al., 2006), across wet and dry landscape positions (Davidson et al., 1998; Pacific et al., 2008, 2009; Riveros-Iregui et al., 2008; Webster et al., 2008), and as a result of the distribution, quantity, and quality of organic matter (Raymment and Jarvis, 2000; Epron et al., 2004; Webster et al., 2008). More recently, it has been demonstrated that at large scales $\left(\sim \mathrm{km}^{2}\right)$, the spatial variability of soil respiration is organized by landscape morphology and structure (Riveros-Iregui and McGlynn, 2009), and that this large spatial variability can even result in opposing responses of soil respiration to climatic forcing (Pacific et al., 2009). While progress has been made in understanding the controls of soil respiration variability, one area that needs further investigation is the influence of groundwater table dynamics and landscape structure and attributes, which is the focus of this study.

It has been suggested that $70 \%$ of the western US carbon sink occurs at elevations above $750 \mathrm{~m}$ (Schimel et al., 2002), and often in complex topography, which we define here as $5-45 \%$ slopes, combined topographic convergence and divergence, contrasting aspects, multiple landscape elements, variable groundwater dynamics, and heterogeneous land cover. Therefore, it is essential to understand and consider the role of landscape position and biophysical gradients as drivers of soil respiration in these montane settings.

It is well established that $\mathrm{CO}_{2}$ in soil pore spaces is primarily the result of autotrophic (root) and heterotrophic (microbial) respiration. Soil $\mathrm{CO}_{2}$ production is 
generally controlled by soil temperature and soil water content (SWC) (Raich and Schlesinger, 1992; Fang and Moncrieff, 1999; Tang and Baldocchi, 2005), as well as the availability of soil organic matter (SOM) (Schuur and Trumbore, 2006; Scott-Denton et al., 2006). Traditionally, it is accepted that increases in both soil temperature (Fang and Moncrieff, 2001; Yuste et al., 2007; Xu and Wan, 2008) and SWC (Davidson et al., 1998, 2000; Liu and Li, 2005; Risch and Frank, 2007) promote higher soil $\mathrm{CO}_{2}$ production. However, soil respiration rates can quickly decline when soils are very wet (Happell and Chanton, 1993; Davidson et al., 1998; Gulledge and Schimel, 2000) or very dry (Conant et al., 1998; Welsch and Hornberger, 2004; Riveros-Iregui et al., 2007, 2008). Increased soil $\mathrm{CO}_{2}$ production has also been attributed to greater root exudation at times of high photosynthetic activity (Baldocchi et al., 2006), which can stimulate soil heterotrophic activity.

The efflux of $\mathrm{CO}_{2}$ from the soil to the atmosphere is the balance between soil $\mathrm{CO}_{2}$ production and soil gas diffusivity (i.e. transport through the soil profile). An increase in SWC often leads to higher soil $\mathrm{CO}_{2}$ production (Davidson et al., 1998, 2000), but can simultaneously reduce soil gas transport (Millington, 1959; Washington et al., 1994; Moldrup et al., 2000, 2001). This production-transport relationship can result in short-term efflux equifinality (i.e. comparable outcomes with different combinations of the variables) across landscapes where SWC-mediated $\mathrm{CO}_{2}$ production and transport are spatially variable (Pacific et al., 2008). For example, Pacific et al. (2008) found that despite concentration gradients from the soil to the atmosphere that were nearly an order of magnitude higher in riparian versus hillslope zones, efflux was similar across short (daily) timescales. Their work suggested that surface $\mathrm{CO}_{2}$ efflux in wet riparian soils was limited by low soil gas transport (despite high soil $\mathrm{CO}_{2}$ concentrations), whereas efflux in dry hillslope soils was limited by low soil gas production (despite high soil gas diffusivity), resulting in similar efflux. McCarthy and Brown (2006) and Sotta et al. (2006) also found similar efflux across upland and lowland positions under significantly different SWC.

Significant differences in the drivers of soil respiration can exist as a function of landscape position. For example, higher SWC and higher and more persistent groundwater tables are often observed in convergent (Dunne and Black, 1970; Anderson and Burt, 1978; McGlynn and Seibert, 2003), depressional (Parkin et al., 2005), lower slope positions (Sotta et al., 2006; Pacific et al., 2008; Xu and Wan, 2008), and locations with high upslope accumulated area (UAA, a measure of the area of land draining to a particular location) (Jencso et al., 2009; Pacific et al., 2010). This variability in SWC can in turn affect other soil respiration-driving variables, such as the abundance of SOM (Ostendorf, 1996; Sjogersten et al., 2006) and magnitude of soil gas diffusivity (Millington, 1959; Moldrup et al., 2001; Schwendenmann et al., 2003; Sotta et al., 2007). Aspect can be a strong control on soil temperature, with higher soil temperatures generally found on south-facing slopes in the northern hemi- sphere (Kang et al., 2006). Spatial variability in vegetation can also influence soil respiration due to differences in root respiration and the quantity and quality of detritus (Raich and Tufekcioglu, 2000). These biophysical gradients across landscape positions can lead to strong spatial heterogeneity in soil respiration.

Riparian and hillslope zones are two dominant landscape elements in headwater catchments and generally have distinct SWC and groundwater table regimes, leading to differences in soil and vegetation characteristics (Hill, 1996; McGlynn and Seibert, 2003). The riparian zone can be defined as the near-stream area between the hillslope and stream channel (Seibert and McGlynn, 2005), and is often characterized by hydromorphic soils (Phillips et al., 2001; Cosanday et al., 2003; Mourier et al., 2008), high SOM (McGlynn and McDonnell, 2003; Hill and Cardaci, 2004; Hill et al., 2004; Gurwick et al., 2008), and a marked decrease in slope from the adjacent hillslope zone over very short distances $(\sim 1 \mathrm{~m})$ (Merot et al., 1995; Jencso et al., 2009). The transition between riparian and hillslope zones offers unique opportunities to investigate the role of landscape position and biophysical variables on soil respiration due to strong gradients of SWC, soil temperature, soil gas diffusivity and SOM, and variable groundwater dynamics, all of which arise over short spatial scales. We present measurements of growing season (June-August) surface $\mathrm{CO}_{2}$ efflux, soil $\mathrm{CO}_{2}$ concentrations, $\mathrm{SWC}$, soil temperature, groundwater dynamics, and soil $\mathrm{C}$ and $\mathrm{N}$ concentrations at 32 positions along eight riparian-hillslope transitions (four locations per transect) in a complex subalpine watershed in the northern Rocky Mountains. We examine how short-scale $(\sim \mathrm{m})$ gradients in biophysical and hydrological controls influence the generation and flux of soil $\mathrm{CO}_{2}$ in a topographically complex watershed. We seek to address the following questions:

1. How do landscape positions and attributes (e.g. slope, UAA, and aspect) relate to spatial and temporal patterns of groundwater depth, SWC, and soil respiration across riparian-hillslope transitions?

2. How does surface $\mathrm{CO}_{2}$ efflux differ between two hydrologically distinct landscape positions: riparian (wet) and hillslope (dry) areas?

3. How can landscape metrics be used to explain dynamics between surface $\mathrm{CO}_{2}$ efflux and SWC or soil temperature across multiple riparian and hillslope positions?

\section{Materials and Methods}

\section{Site description}

This research was conducted in the United States Forest Service Tenderfoot Creek Experimental Forest (TCEF; latitude $46^{\circ} 55^{\prime} \mathrm{N}$, longitude $\left.110^{\circ} 52^{\prime} \mathrm{W}\right)$ within the upper-Stringer Creek Watershed ( 393 ha). The TCEF is located in the Little Belt Mountains within the Lewis and Clark National Forest of central Montana (Figure 1), and 


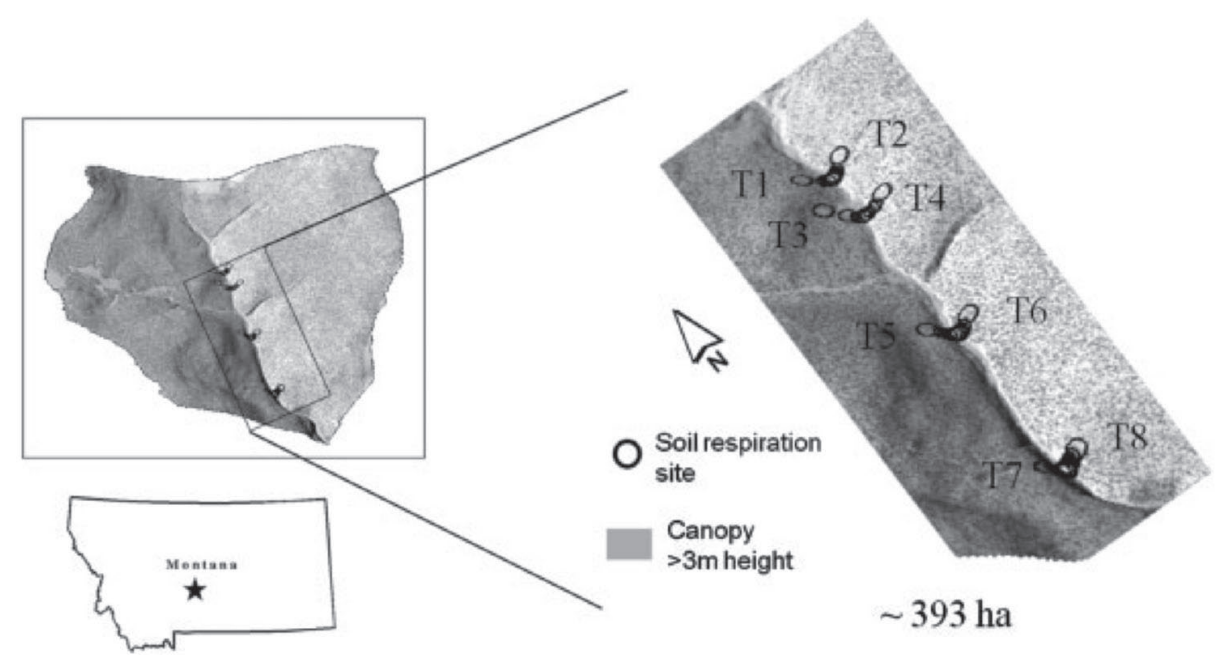

Figure 1. LIDAR (ALSM) topographic image (resolution $<1 \mathrm{~m}$ for bare earth and vegetation) of the upper-Stringer Creek Watershed (393 ha) within the TCEF (Lewis and Clark National Forest), Montana (latitude $46^{\circ} 55^{\prime} \mathrm{N}$, longitude $110^{\circ} 52^{\prime} \mathrm{W}$ ). Transect and soil respiration measurement locations are shown.

is characteristic of subalpine watersheds in the northern Rocky Mountains (wide range of slope, aspect, and topographic convergence/divergence). Elevation ranges from 1840 to $2421 \mathrm{~m}$, with a mean of $2205 \mathrm{~m}$.

The mean annual temperature is $0{ }^{\circ} \mathrm{C}$, with mean daily temperatures ranging from $-8.4^{\circ} \mathrm{C}$ in December to $12.8^{\circ} \mathrm{C}$ in July (Farnes et al., 1995). Annual precipitation averages $880 \mathrm{~mm}$, with $\sim 70 \%$ falling as snow from November to May, with typical snow depths of 1-2 m. We defined the growing season as mid-June to August using an air temperature threshold. This was the approximate time period during which average minimum daily temperatures remained above freezing, based on the 10-year data record from the Natural Resource and Conservation Service Onion Park SNOTEL site located $\sim 2 \mathrm{~km}$ from the transect locations and at approximately the same elevation.

Lodgepole pine (Pinus contorta) is the dominant overstory vegetation (Farnes et al., 1995); subalpine fir (Abies lasiocarpa), Douglas-fir (Pseudotsuga menziesii), Englemann spruce (Picea engelmannii), and whitebark pine (Pinus albicaulis) are also present. Trees are present on the hillslopes along each transect and are generally not found in the riparian areas. Grouse whortleberry ( $\mathrm{Vac}-$ cinium scoparium) is the dominant understory species in the uplands, whereas riparian vegetation is mainly composed of bluejoint reedgrass (Calamagrostis canadensis) (Mincemoyer and Birdsall, 2006). In general, westaspect hillslopes often have a denser canopy cover and later snowmelt in this catchment. The geology is characterized by granite gneiss, shales, quartz porphyry, and quartzite (Farnes et al., 1995), and the most extensive soil types are loamy skeletal, mixed Typic Cryochrepts, and clayey mixed Aquic Cryoboralfs (Holdorf, 1981).

\section{Landscape characterization}

Eight transects ( $\sim 50 \mathrm{~m}$ long) were identified within the upper-Stringer Creek Watershed (Figure 1). Each transect originated at Stringer Creek, which flows north to south, and extended up the fall line through the riparian zones and adjacent hillslopes. The transects were labeled T1 through T8, and located in east-west pairs (odd $=$ west, even $=$ east $)$ along four stream reaches of Stringer Creek. T1 and T2 were the northern-most (upstream) transects, and T7 and T8 the southern-most (downstream) transects. The riparian-hillslope transition was defined by a break in slope, higher and more sustained groundwater tables in the riparian zones (often leading to saturated conditions), difference in soil depth (0.5-1 $\mathrm{m}$ in the hillslopes and 1-2 $\mathrm{m}$ in the riparian zones), change in soil properties (more organic soils in the riparian zones and more mineral soils in the hillslopes) (Seibert and McGlynn, 2007; Jencso et al., 2009), and transition in dominant vegetation (bluejoint reedgrass in the riparian zones and grouse whortleberry in the hillslopes) (Mincemoyer and Birdsall, 2006). Four instrumentation nests were installed along each transect, two each in the riparian and hillslope zones. The nests were labeled 1-4, with 1 being furthest up the hillslope and 4 closest to Stringer Creek. Some nests were reclassified as either riparian or hillslope once data collection began due to groundwater table dynamics (T3-2 as riparian and T2-3, T5-3, and T7-3 as hillslope) (Seibert and McGlynn, 2007).

\section{Terrain analysis}

An airborne laser swath mapping (ALSM) [commonly known as light detection and ranging (LIDAR)] 3-m digital elevation model (DEM) was used to calculate UAA (calculated at the instrument nest closest to the stream on each transect, e.g. T1-4, T2-4) and slope (average slope along the fall line from the highest to lowest hillslope location, e.g. T1-1 to T1-2) along each transect (Seibert and McGlynn, 2007). Riparian zone width was calculated using a Global Positioning System (GPS) survey (Trimble GPS 5700 receiver) (Jencso et al., 2009). The topographic wetness index (TWI), which can be interpreted as a relative wetness index, indicated landscape 
position wetness propensity with the following equation (Beven and Kirkby, 1979):

$$
\mathrm{TWI}=\ln \left(\frac{a}{\tan \beta}\right)
$$

where $a$ is UAA, and $\beta$ is the local slope.

\section{Environmental measurements}

Along each transect, environmental measurements were collected every 1-5 days from June 9 to August 31,2005 . Both volumetric SWC $\left(\mathrm{cm}^{3} \mathrm{H}_{2} \mathrm{O} / \mathrm{cm}^{3}\right.$ soil, integrated over the top $20 \mathrm{~cm}$ of soil; Hydrosense portable SWC meter, Campbell Scientific Inc., Utah, USA) and soil temperature (12-cm soil thermometer, Reotemp Instrument Corporation, San Diego, California, USA; measurement range of -20 to $120^{\circ} \mathrm{C}$, temperature measured at $10 \mathrm{~cm}$ depth) were manually collected within a $1 \mathrm{~m}^{2}$ measurement area at each nest location. SWC was measured three times to capture the variability of SWC at each nest, and the mean of the three measurements was used for data analysis.

The Hydrosense portable SWC meter was calibrated using a time domain reflectometry (TDR) system developed following Robinson et al. (2003). The TDR sensor was tested in the laboratory by comparing TDR and gravimetric measurements over a wide range of SWC (data not shown). Approximately 300 SWC measurements were collected in the field with both instruments. Measurements were comparable in the mineral upland soil $\left(r^{2}=0.99\right)$, but SWC was overestimated by the Hydrosense in the organic riparian soil. The following equation was therefore used to adjust Hydrosense SWC measurements in the organic riparian soil (Pacific et al., 2008):

$$
\begin{aligned}
\text { SWC }= & (0.7704 \times \text { Hydrosense measurement }) \\
& +0.8774\left(r^{2}=0.986\right)
\end{aligned}
$$

\section{Soil carbon and nitrogen concentrations}

At each nest location, two $10-\mathrm{cm}$ soil cores were collected, with the center of each core at the depth of interest $(20$ and $50 \mathrm{~cm})$ with a hand auger $(7.5 \mathrm{~cm}$ diameter, $10 \mathrm{~cm}$ height) from July 26 to 30,2005 . The soil cores were dried, homogenized, sieved (60-mesh, $250 \mu \mathrm{m}$ screen), ground into a fine powder using a mortar and pestle, and weighed and analyzed for total $\mathrm{C}$ and $\mathrm{N}$ concentrations using a $\mathrm{C}$ and $\mathrm{N}$ analyzer (LECO TruSpec $\mathrm{CN}$, Leco Corporation, St. Joseph, Michigan, USA). Molar soil C:N ratios were then calculated.

\section{Soil bulk density and root density}

Bulk density of the upper $5 \mathrm{~cm}$ of soil was measured with a 5-cm diameter bulk density sampler. Soil root density was measured from soil samples collected from the upper $20 \mathrm{~cm}$ of soil using a hand auger $(5 \mathrm{~cm}$ diameter). The samples were dried, and the roots were manually separated and weighed in the laboratory.

\section{Hydrological measurements}

Groundwater wells (screened from the completion depth of $0.5-2 \mathrm{~m}$ to within $0.2 \mathrm{~m}$ of the ground surface) were installed at riparian and lower hillslope nests (i.e. 4, 3, and 2) along each transect. Groundwater levels were recorded every $30 \mathrm{~min}$ using capacitance rods ( \pm 1 mm resolution, Tru Track, Inc., New Zealand). Installation of 24 capacitance rods occurred from the beginning of June until the middle of July (due to limited availability from the manufacturer), and manual measurements of groundwater depth were collected to quantify groundwater dynamics over the entire measurement period. Manual measurements were collected with an electric water level meter every 5-7 days from midJune to mid-July (time period following snowmelt when groundwater dynamics were highly variable), then every 2-4 weeks until the end of August.

\section{Soil $\mathrm{CO}_{2}$ concentration measurements}

Following the methods described by Andrews and Schlesinger (2001) and Welsch and Hornberger (2004), soil air gas wells [15-cm section of $5.25-\mathrm{cm}$ (inside diameter) polyvinyl chloride (PVC)] were installed at completion depths of 20 and $50 \mathrm{~cm}$ at each nest (total of two gas wells per nest). The top of each gas well was capped with a size 11 rubber stopper through which passed two pieces of PVC tubing $(4.8 \mathrm{~mm}$ inside diameter Nalgene 180 clear PVC, Nalge Nunc International, Rochester, New York, USA) that extended above the ground surface. To ensure that no gas escaped while measurements were not being collected, the tubing was joined with plastic connectors $(6-8 \mathrm{~mm}$ high density polyethylene (HDPE) FisherBrand tubing connectors, Fisher Scientific, USA).

Soil air $\mathrm{CO}_{2}$ concentrations were measured by attaching the two sections of gas well tubing to a portable infrared gas analyzer (IRGA) [model EGM-3, accurate to within $1 \%$ of calibrated range $(0-50,000 \mathrm{ppm})$; PP Systems, Massachusetts, USA] or [model GM70 with M170 pump and GMP $221 \mathrm{CO}_{2}$ probe, accurate to within 1\% of calibrated range (0-50 $000 \mathrm{ppm})$; Vaisala, Finland], as performed by Pacific et al. (2008). Two IRGAs were available in case one needed to be recalibrated, and measurements were routinely compared in the field to ensure validity. The air from the gas well was circulated through the IRGA and returned to the gas well, creating a closed loop and minimizing pressure changes during sampling. Both instruments were allowed a 30-min warm-up time (per the manufacturer's recommendations), and after which remained on for the duration of measurements. $\mathrm{CO}_{2}$ concentration measurements required 2-5 min (recirculation time) before stabilized values were recorded. Recirculation time did not affect soil $\mathrm{CO}_{2}$ concentrations in our experimental design or similar designs (Andrews and Schlesinger, 2001; Welsch and Hornberger, 2004; Pacific et al., 2008). Soil $\mathrm{CO}_{2}$ concentration measurements were internally corrected for air temperature and pressure with the EGM-3, and com- 
pensated for air temperature and pressure for the GMP 221 following recommendations by the manufacturer (www.vaisala.com).

\section{Surface $\mathrm{CO}_{2}$ efflux measurements}

A $0.5 \mathrm{~m}^{2}$ surface $\mathrm{CO}_{2}$ efflux plot, roped off to minimize soil trampling, was selected at each nest location. To minimize the effect of above-ground autotrophic respiration inside the chamber, vegetation within the efflux plot was clipped approximately once per week after a round of measurements was collected. Plant roots were left intact to minimize disturbance to below-ground root respiration. A soil respiration chamber [SRC-1 chamber with a footprint of $314.2 \mathrm{~cm}^{2}$, accurate to within $1 \%$ of calibrated range $\left.\left(0-9.99 \mathrm{~g} \mathrm{CO}_{2} \mathrm{~m}^{-2} \mathrm{hr}^{-1}\right)\right]$ in conjunction with an IRGA [EGM-4, accurate to within 1\% of calibrated range (0-2000 ppm); PP Systems, Massachusetts, USA] was used to measure surface $\mathrm{CO}_{2}$ efflux. Three measurements were collected per nest location and averaged for data analysis. The chamber was flushed with ambient air for $15 \mathrm{~s}$ and then inserted $3 \mathrm{~cm}$ into the soil (size of attached collar) before each measurement began. We estimated cumulative efflux from June 9 to August 31, 2005 by linearly interpolating between measurements collected every 2-7 days. Previously demonstrated for this site (Riveros-Iregui et al., 2008; Riveros-Iregui and McGlynn, 2009), this was a robust approach for comparison of efflux measurements across multiple locations over extended periods of time, and that sampling frequency did not bias cumulative efflux estimates.

\section{Soil gas diffusivity}

We inversely calculated "effective" soil gas diffusivity for the upper $20 \mathrm{~cm}$ of the soil profile (which provided an estimate of $D$ in the following equation) using Fick's Law and measured values of surface $\mathrm{CO}_{2}$ efflux, $20 \mathrm{~cm}$ soil $\mathrm{CO}_{2}$ concentrations, and an assumed atmospheric $\mathrm{CO}_{2}$ concentrations of $400 \mathrm{ppm}$ :

$$
\begin{array}{ll}
\text { Flux }=-D & \partial C \\
\partial z & (3)
\end{array}
$$

where $D$ is the diffusivity $\left(\mathrm{m}^{2} \mathrm{~s}^{-1}\right), C$ the $\mathrm{CO}_{2}$ concentration (ppm), and $z$ the depth (m). A recent study demonstrated that the assumed values do not compromise calculation of soil $\mathrm{CO}_{2}$ efflux, as the diel variability of soil $\mathrm{CO}_{2}$ concentration in depth is much greater than the diel variability of $\mathrm{CO}_{2}$ above the soil surface given the atmospheric buffer (Riveros-Iregui et al., 2008).

\section{Statistical analyses}

Analysis of variance (ANOVA) $(\alpha=0.05)$ was used to test for differences in soil $\mathrm{CO}_{2}$ concentrations, soil temperature, SWC, soil gas diffusivity, soil $\mathrm{C}$ and $\mathrm{N}$ concentrations and respective molar soil C:N ratios, and surface $\mathrm{CO}_{2}$ efflux both within transects (riparian versus hillslope) and among the eight transects (riparian versus riparian and hillslope versus hillslope). For comparisons among the eight transects, $n$ ranged from three to eight due to reclassification of some nests as either riparian or hillslope. Separate analyses were performed each month due to the temporal dynamics at this research site (with the exception of soil $\mathrm{C}$ and $\mathrm{N}$ concentrations and respective C:N ratios, as measurements were collected only once). For within-transect analyses, $n$ was higher on T1-4 (ranging from 52 in June to 80 in July on T1-4 versus 24 in August to 44 in June on T5-8, as these transects had a higher sampling frequency (to increase temporal resolution). For comparisons among the 8 transects, $n$ ranged from 24 for T7 versus T8 in June to 80 for T1 versus $\mathrm{T} 2$ in July. Three measurements of SWC and surface $\mathrm{CO}_{2}$ efflux were collected at each nest location on all sampling days and averaged for data analysis. To test the validity of the ANOVA approach and test for autocorrelation problems, we performed autocorrelation tests, which showed that our measurements had little to no temporal dependence over the monthly timescales used for the ANOVA analysis. Regression analysis was performed to assess the strength of the relationship between surface $\mathrm{CO}_{2}$ efflux and SWC or soil temperature. Note that T1-2 efflux was unusually high and excluded from statistical analyses (except as presented in Figure 4).

\section{Results}

\section{Landscape analysis}

Landscape characterization results are summarized in Table I. UAA ranged from $1023 \mathrm{~m}^{2}$ on $\mathrm{T} 6$ to $14,783 \mathrm{~m}^{2}$ on T4, with the lowest values on downstream transects. The slope of the hillslopes generally increased moving downstream, ranging from $13.6 \%$ on T2 to $42.5 \%$ on T8. Riparian zone width ranged from $21.0 \mathrm{~m}$ on T3 to $4.7 \mathrm{~m}$ on T7, and was typically wider on upstream transects. TWI was in general highest on upstream transects and ranged from 8.0 on $\mathrm{T} 8$ to 11.5 on $\mathrm{T} 3$.

Table I. Landscape characterization of UAA, riparian zone width, predominate slope of hillslope, TWI, and median depth of groundwater (in the riparian zone) on each transect

\begin{tabular}{lcclrr}
\hline Transect & $\begin{array}{l}\text { UAA } \\
\left(\mathrm{m}^{2}\right)\end{array}$ & $\begin{array}{l}\text { Riparian } \\
\text { width } \\
(\mathrm{m})\end{array}$ & $\begin{array}{l}\text { Hillslope } \\
\text { slope } \\
(\%)\end{array}$ & TWI & \multicolumn{1}{c}{$\begin{array}{c}\text { Depth to } \\
\text { GW }(\mathrm{med}) \\
(\mathrm{cm})\end{array}$} \\
\hline 1 & 2249 & 12.7 & 18.1 & 9.4 & 14.5 \\
2 & 1804 & 11.8 & 13.6 & 9.5 & 11 \\
3 & 14,304 & 21.0 & 14.6 & 11.5 & 24 \\
4 & 14,783 & 8.3 & 30.0 & 10.8 & 35 \\
5 & 14,304 & 11.7 & 24.0 & 11.0 & 40 \\
6 & 1023 & 6.5 & 21.4 & 8.5 & 47.5 \\
7 & 1373 & 4.7 & 41.7 & 8.0 & $>100$ \\
8 & 1755 & 9.9 & 42.5 & 8.3 & 49 \\
\hline
\end{tabular}

UAA and slope were calculated using 3-m DEMs (Seibert and McGlynn, 2007). Transects 1 and 2 (east-west pair) are located furthest upstream, whereas Transects 7 and 8 (east-west pair) are located furthest downstream. On T7, no groundwater table development was observed above the well completion depth of $100 \mathrm{~cm}$. 
Soil carbon and nitrogen concentrations and molar C:N ratios

In the riparian zones, the mean and standard deviation of soil C concentrations were 2.3 and $1.1 \%$ at $20 \mathrm{~cm}$ and 1.8 and $0.9 \%$, respectively, at $50 \mathrm{~cm}$. In the hillslopes, soil $\mathrm{C}$ concentrations had a mean and standard deviation of 2.7 and $1.8 \%$ at $20 \mathrm{~cm}$ and 1.3 and $0.7 \%$, respectively, at $50 \mathrm{~cm}$. The mean and standard deviation of riparian zone soil $\mathrm{N}$ concentrations were 18 and $0.09 \%$, respectively, at $20 \mathrm{~cm}$, and 10 and $0.05 \%$ at $50 \mathrm{~cm}$. Hillslope soil $\mathrm{N}$ concentrations had a mean and standard deviation of 0.12 and $0.06 \%$ at $20 \mathrm{~cm}$, and 0.06 and $0.05 \%$, respectively, at $50 \mathrm{~cm}$.

There were differences in riparian versus hillslope molar soil C: $\mathrm{N}$ ratios within transects, with higher ratios in the hillslopes on T1, T3, and T4 at $20 \mathrm{~cm}$, and on T3 and T4 at $50 \mathrm{~cm}$ (Figure 2). Overall, riparian molar soil C:N ratios had a mean and standard deviation of 14.1:1 and 2.6:1, respectively, at $20 \mathrm{~cm}$, and $18: 1$ and 3.5:1 at 50 $\mathrm{cm}$. In the hillslopes, the mean and standard deviation of molar soil C:N ratios were 30.6:1 and 10.1:1, respectively, at $20 \mathrm{~cm}$, and 32.3:1 and 13.9:1 at $50 \mathrm{~cm}$. There was also a general trend of decreasing molar soil C:N ratios from hillslope to riparian zones along each transect (Figure 2). Few differences in $20-$ and $50-\mathrm{cm}$ molar soil C:N ratios were observed when comparing hillslope zones among the eight transects. However, there were often differences between the riparian zones of each transect. T2, T4, and T7 had higher, and T3, T6, and T8 lower riparian molar C:N ratios than other transects (Figure 2).

\section{Soil bulk density and root density}

In the riparian zones, soil bulk density had a mean and standard deviation of 0.962 and $0.046 \mathrm{~g} \mathrm{~cm}^{-3}$, respectively, compared with 0.911 and $0.076 \mathrm{~g} \mathrm{~cm}^{-3}$ in the hillslopes. Riparian zone soil root density had a mean and standard deviation of 11.5 and $2.5 \mathrm{~g}$ root $\mathrm{kg}^{-1}$ soil, respectively, compared to 9.6 and $4.2 \mathrm{~g}$ root $\mathrm{kg}^{-1}$ soil in the hillslopes. These differences in riparian and hillslope soil bulk density and root density were not significant.

\section{Soil temperature}

Soil temperature was not significantly different between riparian and hillslope zones within each transect (with the exception of localized differences on T3, T4, and T8 during June and July) (Table II, Figures 3-5). There were, however, significant differences in both riparian and hillslope zones between the eight transects (Figure 6). Colder soil temperatures were found during June and July on transects with a west aspect (even numbered transects), where snow was observed up to 3 weeks later than transects with an east aspect (particularly in the hillslopes). The number of significant differences in soil temperature among the eight transects decreased from June to August (Figure 6).

\section{Soil water content}

SWC (integrated over top $20 \mathrm{~cm}$ ) was significantly higher in the riparian zones within each transect during
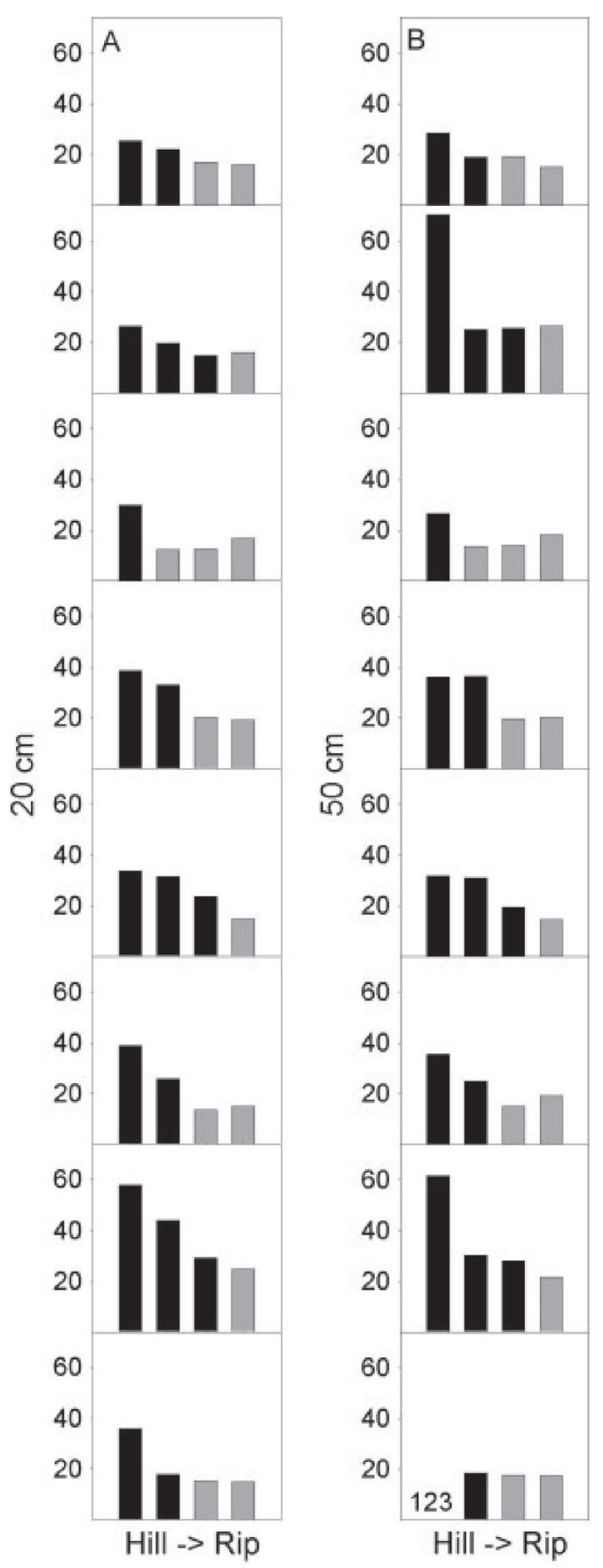

Figure 2. Bar graphs of soil C:N ratios in hillslope (black) and riparian (grey) zones along each transect at (A) $20 \mathrm{~cm}$ and (B) $50 \mathrm{~cm}$. Note that a very high value was observed at T8-1 at $50 \mathrm{~cm}(123: 1)$, and the value is written instead of plotted so as not to affect the bar graph scale.

the entire period of this study (Table II; Figures 3, 4, and 7). There were also significant differences when comparing both riparian and hillslope zones between the eight transects (Figure 8), with higher SWC generally measured on upstream transects (i.e. T1-4 versus T5-8). A general downstream decrease in SWC was observed, with a more pronounced trend in the riparian zones (Figure 3). 
Table II. Analysis of variance statistics $(\alpha=0.05)$ for riparian versus hillslope soil $\mathrm{CO}_{2}$ concentrations $(20$ and $50 \mathrm{~cm}$ ), soil temperature, soil water content, surface $\mathrm{CO}_{2}$ efflux, and soil gas diffusivity during June, July, and August, 2005

\begin{tabular}{|c|c|c|c|c|c|c|c|}
\hline Transect & $n$ & $\mathrm{CO}_{2}-20$ & $\mathrm{CO}_{2}-50$ & Temp & SWC & Efflux & Diff \\
\hline \multicolumn{8}{|l|}{ June } \\
\hline 1 & 52 & $\ll 0.01$ & $\ll 0.01$ & 0.16 & $\ll 0.01$ & $\ll 0.01$ & $\ll 0.01$ \\
\hline 2 & 52 & $\ll 0.01$ & $\ll 0.01$ & 0.21 & $\ll 0.01$ & 0.24 & $\ll 0.01$ \\
\hline 3 & 52 & $\ll 0.01$ & $\ll 0.01$ & $\ll 0.01$ & $\ll 0.01$ & 0.67 & 0.43 \\
\hline 4 & 52 & $\ll 0.01$ & $\ll 0.01$ & $\ll 0.01$ & $\ll 0.01$ & 0.12 & $\ll 0.01$ \\
\hline 5 & 44 & $\ll 0.01$ & 0.41 & 0.86 & $\ll 0.01$ & 0.82 & $\ll 0.01$ \\
\hline 6 & 44 & $\ll 0.01$ & $\ll 0.01$ & 0.48 & $\ll 0.01$ & 0.74 & $\ll 0.01$ \\
\hline 7 & 24 & $\ll 0.01$ & $\ll 0.01$ & 0.98 & $\ll 0.01$ & 0.21 & 0.09 \\
\hline 8 & 24 & $\ll 0.01$ & $\ll 0.01$ & $\ll 0.01$ & $\ll 0.01$ & 0.50 & $\ll 0.01$ \\
\hline \multicolumn{8}{|l|}{ July } \\
\hline 1 & 80 & $\ll 0.01$ & $\ll 0.01$ & 0.57 & $\ll 0.01$ & 0.14 & $\ll 0.01$ \\
\hline 2 & 80 & $\ll 0.01$ & $\ll 0.01$ & 0.41 & $\ll 0.01$ & $\ll 0.01$ & 0.04 \\
\hline 3 & 80 & $\ll 0.01$ & $\ll 0.01$ & 0.07 & $\ll 0.01$ & 0.30 & $\ll 0.01$ \\
\hline 4 & 80 & $\ll 0.01$ & 0.12 & $\ll 0.01$ & $\ll 0.01$ & 0.13 & $\ll 0.01$ \\
\hline 5 & 36 & $\ll 0.01$ & 0.04 & 0.75 & $\ll 0.01$ & 0.33 & 0.01 \\
\hline 6 & 36 & $\ll 0.01$ & $\ll 0.01$ & 0.94 & $\ll 0.01$ & $\ll 0.01$ & 0.04 \\
\hline 7 & 28 & $\ll 0.01$ & $\ll 0.01$ & 0.66 & $\ll 0.01$ & $\ll 0.01$ & 0.12 \\
\hline 8 & 28 & $\ll 0.01$ & $\ll 0.01$ & $\ll 0.01$ & $\ll 0.01$ & 0.09 & $\ll 0.01$ \\
\hline \multicolumn{8}{|l|}{ August } \\
\hline 1 & 56 & $\ll 0.01$ & $\ll 0.01$ & 0.70 & $\ll 0.01$ & $\ll 0.01$ & $\ll 0.01$ \\
\hline 2 & 56 & $\ll 0.01$ & $\ll 0.01$ & 0.62 & $\ll 0.01$ & $\ll 0.01$ & $\ll 0.01$ \\
\hline 3 & 56 & $\ll 0.01$ & $\ll 0.01$ & 0.97 & $\ll 0.01$ & $\ll 0.01$ & $\ll 0.01$ \\
\hline 4 & 56 & $\ll 0.01$ & 0.01 & 0.18 & $\ll 0.01$ & 0.52 & 0.01 \\
\hline 5 & 24 & $\ll 0.01$ & $\ll 0.01$ & 0.94 & $\ll 0.01$ & 0.09 & $\ll 0.01$ \\
\hline 6 & 24 & $\ll 0.01$ & $\ll 0.01$ & 0.70 & $\ll 0.01$ & $\ll 0.01$ & $\ll 0.01$ \\
\hline 7 & 24 & $\ll 0.01$ & $\ll 0.01$ & 0.64 & $\ll 0.01$ & $\ll 0.01$ & 0.11 \\
\hline 8 & 24 & $\ll 0.01$ & $\ll 0.01$ & 0.22 & $\ll 0.01$ & $\ll 0.01$ & 0.67 \\
\hline
\end{tabular}

Bold numbers indicate statistically significant differences.

\section{Groundwater depth}

In the riparian zones on each transect, the depth of the groundwater table was generally within $20 \mathrm{~cm}$ of the ground surface at all wells at the beginning of June. The groundwater table then gradually declined at all locations throughout the measurement period. Hillslope groundwater table development was not observed on any transect over the course of this study; however, transient hillslope groundwater tables have been observed on some transects during peak snowmelt (Jencso et al., 2010). Higher and more persistent riparian groundwater levels were often observed on upstream transects, where UAA is large, hillslopes are gentle, and TWI is high (Table I). The median depth of groundwater in the riparian zones on upstream transects over the study period ranged from 11 to $35 \mathrm{~cm}$ below the ground surface, and from 40 to $>100 \mathrm{~cm}$ below the ground surface on downstream transects (Table I).

Real-time groundwater table dynamics from the T1-4 and T6-4 measurement locations are presented in Figure 9 to highlight contrasting water table and surface $\mathrm{CO}_{2}$ efflux dynamics between areas with large differences in UAA, slope, and TWI. At T1-4 (upstream transect, high TWI), the groundwater table was at the ground surface (saturation) at the beginning of June.
Saturation persisted until the beginning of July, and then the groundwater table gradually declined to $10 \mathrm{~cm}$ below the ground surface by the end of August, with a median depth of $5.1 \mathrm{~cm}$ over the measurement period. In contrast, at T6-4 (downstream transect, low TWI), the groundwater table was $10 \mathrm{~cm}$ below the ground surface at the beginning of June, but quickly declined to $30 \mathrm{~cm}$ by the end of June. The groundwater table then gradually declined for the remainder of the study period, reaching a maximum depth of $42 \mathrm{~cm}$ below the ground surface by the end of August. Median depth of the groundwater table over the course of this study at T6-4 was $33.6 \mathrm{~cm}$ below the ground surface.

\section{Soil $\mathrm{CO}_{2}$ concentrations}

There were significant differences between riparian and hillslope soil $\mathrm{CO}_{2}$ concentrations within each transect (Table II). Higher concentrations were generally measured at $20 \mathrm{~cm}$ in the riparian zones, whereas at $50 \mathrm{~cm}$, higher concentrations were found in the hillslopes (Figure 3). There were also significant differences in soil $\mathrm{CO}_{2}$ concentrations among the eight transects in both riparian and hillslope zones (Figures 3 and 8 ). At $20 \mathrm{~cm}$, soil $\mathrm{CO}_{2}$ concentrations in the riparian zone along $\mathrm{T} 8$ were always lower than other transects (with a few exceptions in August), and higher concentrations were often observed on T1. In the hillslopes, there were significant differences in $20 \mathrm{~cm}$ soil $\mathrm{CO}_{2}$ concentrations among many transects in June, with fewer differences observed during July and August (Figure 8). Many $50 \mathrm{~cm}$ riparian zone soil $\mathrm{CO}_{2}$ gas wells remained saturated by groundwater over the course of this study, and soil $\mathrm{CO}_{2}$ concentrations could not be measured at these locations (denoted by flat lines in Figure 3D). Soil $\mathrm{CO}_{2}$ concentrations at $50 \mathrm{~cm}$ could therefore not be compared among many transects (indicated by dashed lines in Figure 8). In general, there was a downstream decrease in soil $\mathrm{CO}_{2}$ concentrations in the riparian and hillslope zones at both 20 and $50 \mathrm{~cm}$ (Figure 3). The downstream decrease of soil $\mathrm{CO}_{2}$ concentration magnitude and variability was much more pronounced in the riparian zones, particularly at $20 \mathrm{~cm}$.

\section{Surface $\mathrm{CO}_{2}$ efflux}

In general, monthly averaged soil surface $\mathrm{CO}_{2}$ efflux was not significantly different between riparian and hillslope zones within each transect based on ANOVA analysis (Table II). With the exception of T1, similar ranges and median values were observed in riparian and hillslope zones within each transect when grouping all data from June to August (Figure 3). Note that T1-2 efflux was unusually high and excluded from statistical analyses and is not presented in other figures. Differences in median efflux between riparian and hillslope zones within each transect were generally less than $0.1 \mathrm{~g}$ $\mathrm{CO}_{2} \mathrm{~m}^{-2} \mathrm{hr}^{-1}$, and similar minimum and maximum values were observed (Figure 3). However, significantly higher riparian zone efflux $(p<0.01)(25 \%$ higher in the riparian zones) became apparent when examining median cumulative efflux across all transects during the 

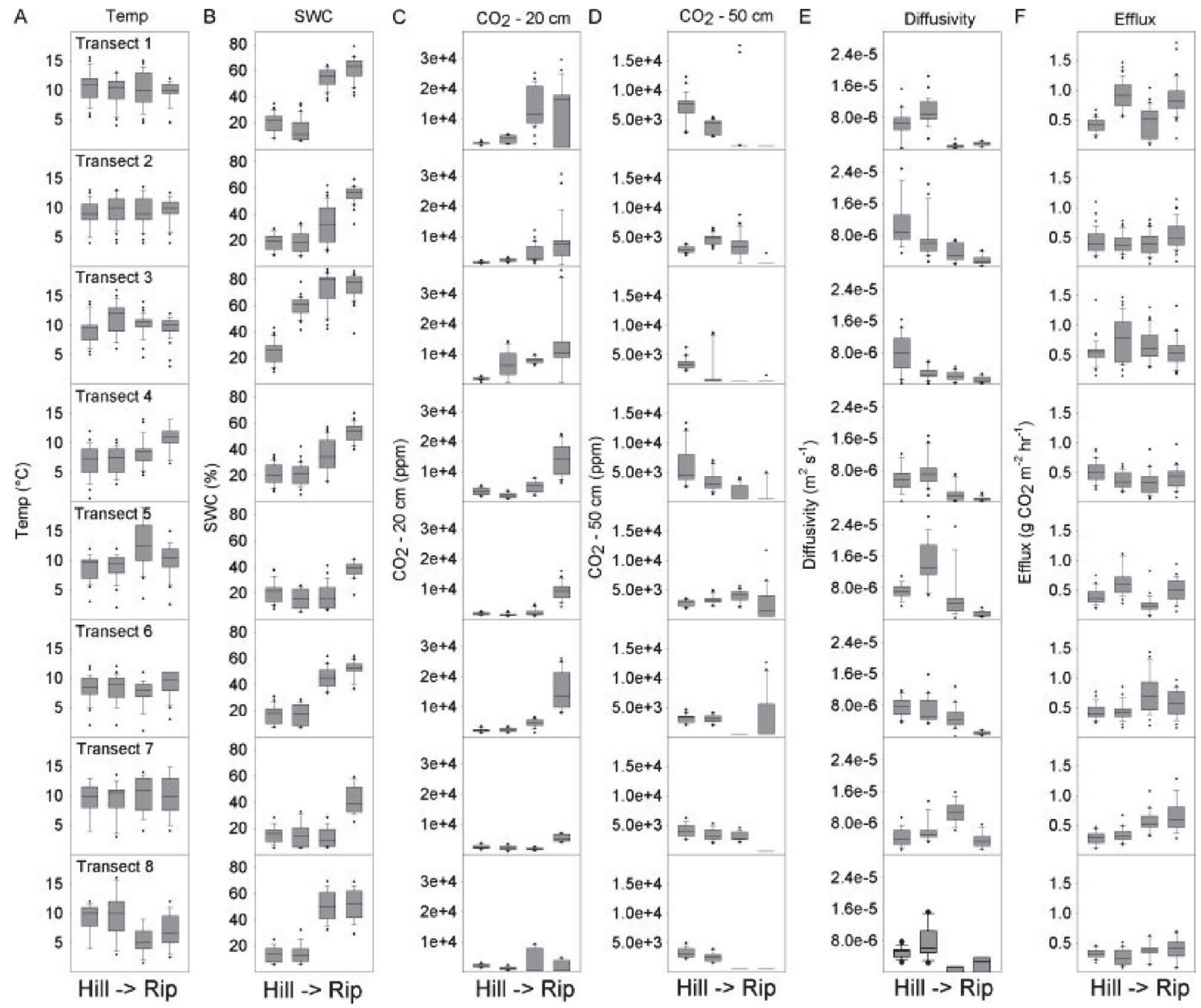

Figure 3. Box-plots of (A) soil temperature, (B) soil water content; (C) soil $\mathrm{CO}_{2}$ concentration - $20 \mathrm{~cm}$; (D) soil $\mathrm{CO}_{2}$ concentration -50 cm; (E) soil gas diffusivity; and (F) surface $\mathrm{CO}_{2}$ efflux along each transect from June 9 to August 31, 2005.
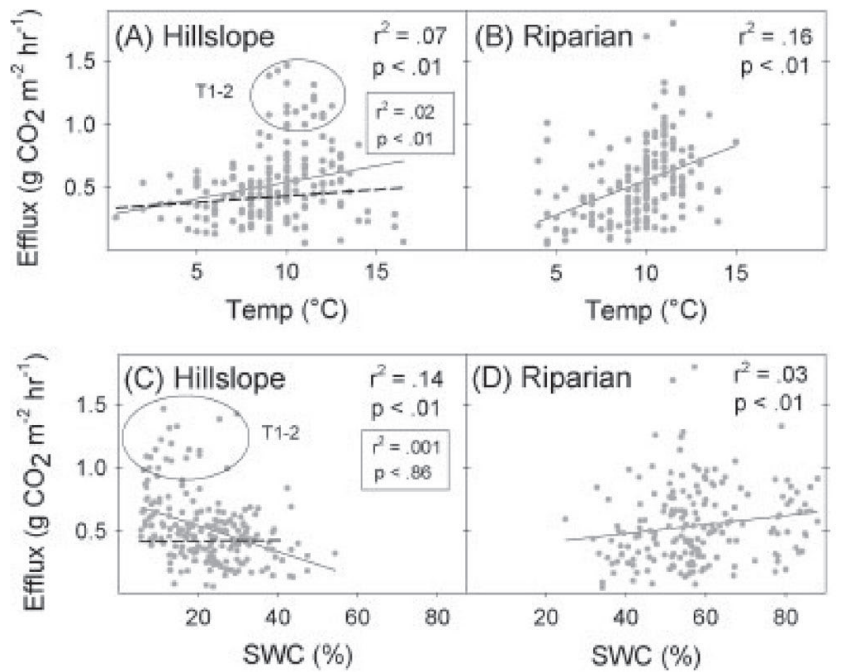

Figure 4. Bivariate plots of soil temperature and surface $\mathrm{CO}_{2}$ efflux at (A) hillslope and (B) riparian zones; and SWC and surface $\mathrm{CO}_{2}$ efflux at (C) hillslope and (D) riparian zones from all transects collected from June 9 to August 31, 2005. Solid line denotes linear regression, and $p$ values are provided for at $\alpha=0.05$. Circles show data from T1-2, and boxes and dashed line show $p$-values and $r^{2}$ with this data removed from analysis. growing season, which we define here as the 83-day period between June 9 and August 31. Riparian cumulative efflux ranged from 649 to $1918 \mathrm{~g} \mathrm{CO}_{2} \mathrm{~m}^{-2}$ during the growing season, with a mean and standard deviation of 1012 and $354 \mathrm{~g} \mathrm{CO}_{2} \mathrm{~m}^{-2}$ during the growing season, respectively (Figure 10). In contrast, hillslope cumulative efflux ranged from 432 to $1246 \mathrm{~g} \mathrm{CO}_{2} \mathrm{~m}^{-2}$ during the growing season (excluding T1-2, which had a cumulative efflux of $1774 \mathrm{~g} \mathrm{CO}_{2} \mathrm{~m}^{-2}$ during the growing season), with a mean and standard deviation of 809 and 222 $\mathrm{g} \mathrm{CO}_{2} \mathrm{~m}^{-2}$ during the growing season, respectively (Figure 10). At T1-4 and T6-4, shown in Figure 9, cumulative growing season efflux was 1918 and $1025 \mathrm{~g} \mathrm{CO}_{2} \mathrm{~m}^{-2}$ during the 83-day growing season, respectively.

Significant differences in monthly efflux among the eight transects were observed in both riparian and hillslope zones during June, July, and August (Figure 8). Median cumulative efflux during the growing season decreased with distance from channel head and ranged from $1160 \mathrm{~g} \mathrm{CO}_{2} \mathrm{~m}^{-2}$ during the growing season on $\mathrm{T} 1 /$ T2 (200 m from channel head) to $810 \mathrm{~g} \mathrm{CO}_{2} \mathrm{~m}^{-2}$ during the growing season on T7/T8 (1400 m from channel head) (Figure 10). 


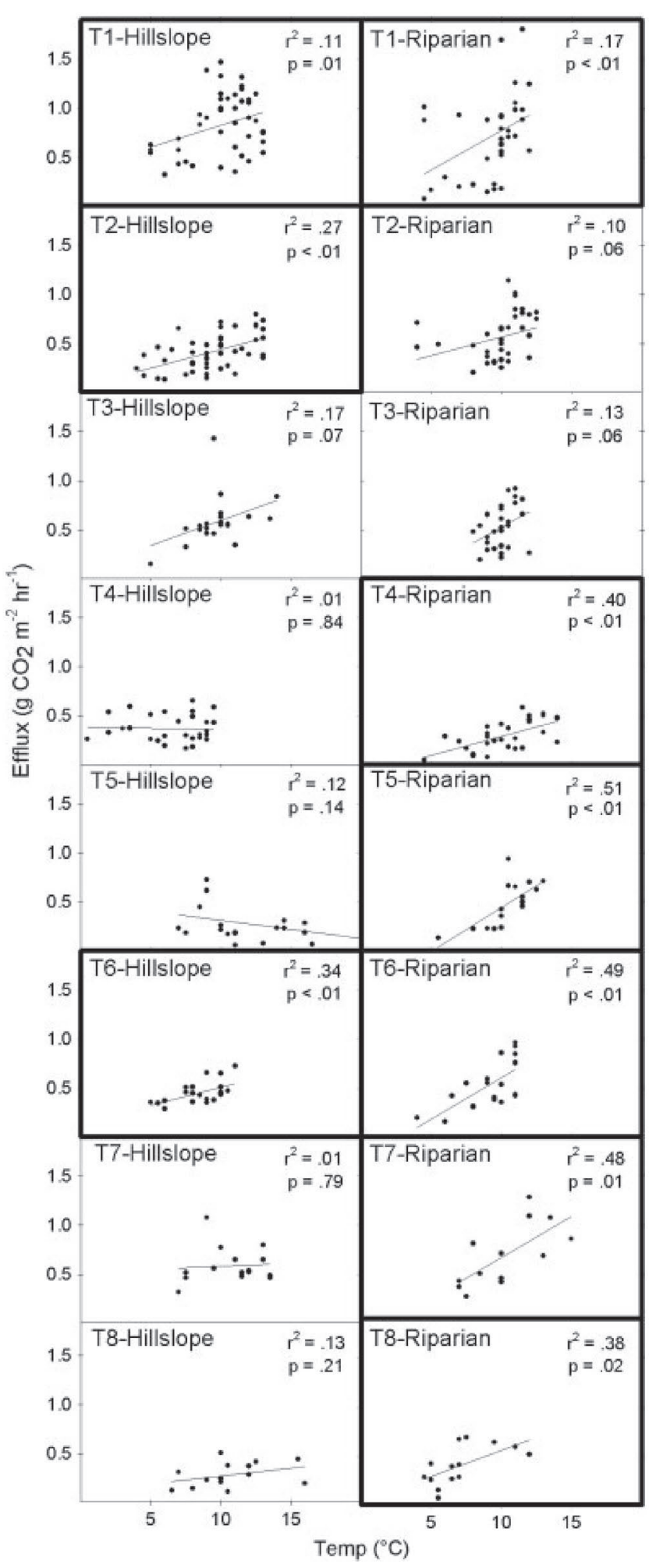

Figure 5. Bivariate plots of soil temperature and surface $\mathrm{CO}_{2}$ efflux at riparian and hillslope zones along each transect, collected from June 9 to August 31, 2005. Solid line denotes linear regression, and $p$-values are provided for at $\alpha=0.05$. Dark boxes indicate a statistically significant relationship.

There was no consistent relationship between surface $\mathrm{CO}_{2}$ efflux and growing season soil temperature or SWC across all transects (Figure 4). Although statisti- cally significant $(p<0.01)$ in both riparian and hillslope zones when all data were grouped together (Figure 4), these relationships showed low explanatory power (low $r^{2}$ values). Furthermore, when T1-2 was excluded from data analysis (Figure 4), the relationships became weaker, and in the case of hillslope efflux versus SWC, they were not significant (Figure 4C). When examining the data by individual transects, there were often significant relationships between surface $\mathrm{CO}_{2}$ efflux and soil temperature, particularly in the riparian zones (Figure 5). However, the relationships were weak, and one relationship did not hold across all transects. Few significant relationships were found between efflux and SWC in both the riparian and hillslope zones across each transect (Figure 7).

\section{Soil gas diffusivity}

Significant differences between riparian and hillslope soil gas diffusivity were found within nearly all transects during both June and July (Table II), with higher diffusivity rates in the hillslopes along all transects (Figure 3). Riparian zone soil gas diffusivity varied significantly among most transects, whereas few differences were found among hillslopes (Figure 6).

\section{Discussion}

How do landscape positions and attributes (e.g. slope, $U A A$, and aspect) relate to spatial and temporal patterns of groundwater depth, SWC, and soil respiration across riparian-hillslope transitions?

Our results indicate that soil respiration varied across riparian and hillslope zones in the upper-Stringer Creek Watershed, which was potentially influenced by differences in landscape position and attributes, and associated spatial patterns of groundwater dynamics and soil wetness status. Consistent with prior observations at this site (Riveros-Iregui and McGlynn, 2009), we found that cumulative growing season soil respiration in grassy riparian zones was significantly higher than in the forested hillslopes, allowing for first-order discretization of the landscape into riparian meadows and upland forests. However, our results suggest that even within riparian areas, cumulative surface $\mathrm{CO}_{2}$ efflux across the growing season was also landscape-controlled, with generally higher soil respiration on upstream transects (near the stream headwaters, Figure 11) and decreasing in the downstream direction. This was perhaps the result of higher upstream SWC and differences in riparian area width, UAA, slope, and groundwater table dynamics.

The relationship between slope, UAA, and SWC can be described by the TWI (Beven and Kirkby, 1979; Equation 1), which suggests that the wettest landscape positions will occur in areas with large UAA and gentle slopes (which therefore have high TWI values) (Bonell, 1998). This relationship was applicable in the upperStringer Creek Watershed, where higher SWC (Figure 7) and more persistent groundwater table development (average depth often less than $25 \mathrm{~cm}$ below the ground 

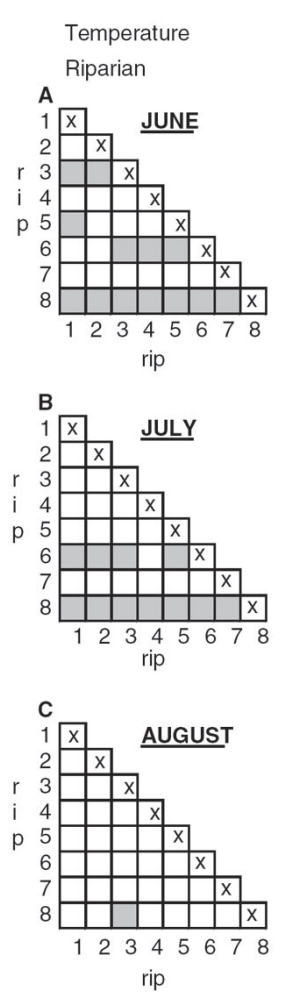
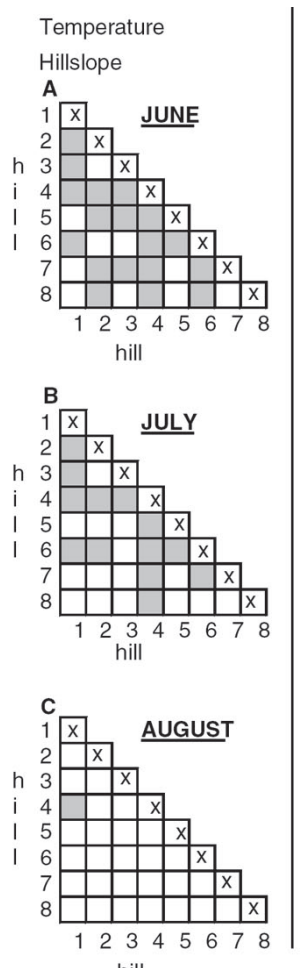

hill

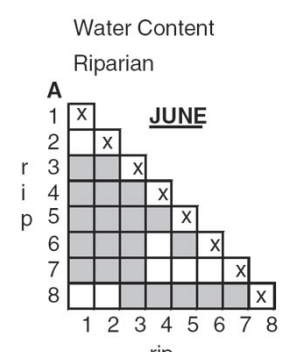

rip
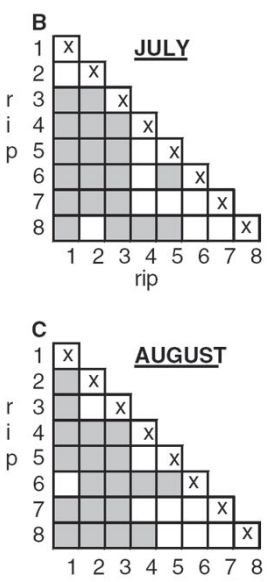

rip
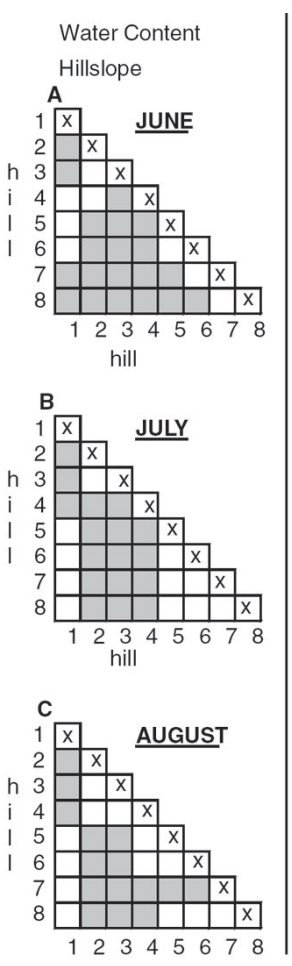

hill

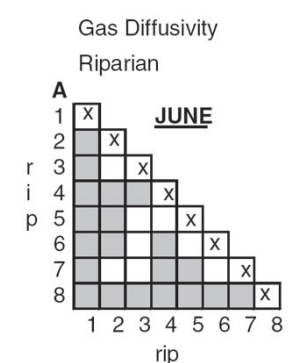

rip
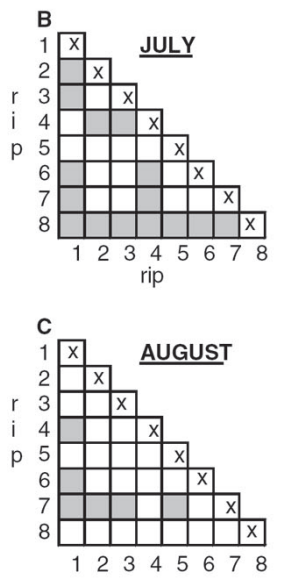

rip
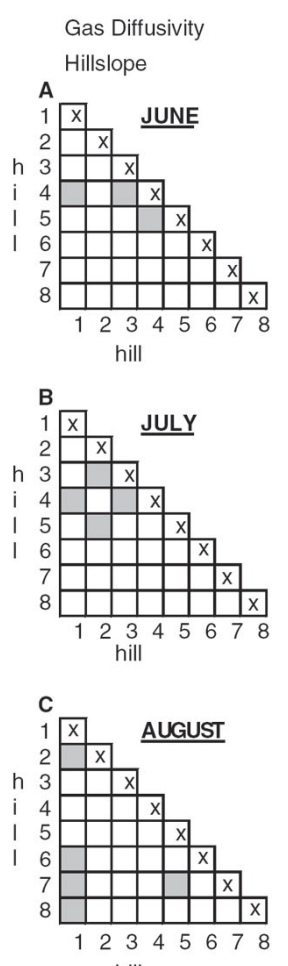

hill

Figure 6. ANOVA statistics $(\alpha=0.05)$ for transect-versus-transect comparisons of riparian and hillslope soil temperature, water content, and gas diffusivity during (A) June, (B) July, and (C) August, 2005. Shaded boxes indicate significant differences. $n$ ranged from 24 for T7 versus T8 in June to 80 for T1 versus T2 in July.

surface over the course of the study) was observed on upstream transects, which are characterized by high UAA and gentle slopes (Table I). For example, T3 has high UAA and a very gentle slope, which resulted in a high TWI (11.5, Table I) and suggested that wetness status would be high (Beven and Kirkby, 1979; Bonell, 1998). This premise held true as SWC was high (Figure 7) and the groundwater table remained relatively close to the ground surface in the riparian zone on T3 (median depth of $24 \mathrm{~cm}$ below the ground surface). In contrast to upstream transects, UAA and the TWI were much lower and slopes much steeper on downstream transects (Table I). For example, UAA is small and slopes are steep on T7, and this resulted in much lower TWI (8.0) and SWC (Figure 3). At this location, the groundwater table never developed above the well completion depth of $100 \mathrm{~cm}$. Based on our understanding of the relationships between soil wetness status, $\mathrm{CO}_{2}$ efflux, and the TWI, higher efflux was expected along T3, where wetness status was higher, as increased SWC generally promotes higher rates of soil respiration (Davidson et al., 1998, 2000; Liu and Li, 2005; Risch and Frank, 2007). Cumulative efflux was $1193 \mathrm{~g} \mathrm{CO}_{2} \mathrm{~m}^{-2}$ during the growing season on $\mathrm{T} 3$ (wet), while only $960 \mathrm{~g} \mathrm{CO}_{2} \mathrm{~m}^{-2}$ during the growing season on T7 (dry), confirming expectations based on topographic analysis and observations made across the entire forest (Riveros-Iregui and McGlynn, 2009). Thus, the concept of the TWI shows promise as an indicator of soil respiration across complex landscapes and is useful for interpretation of surface $\mathrm{CO}_{2}$ efflux in a landscape context.
The downstream decrease in cumulative growing season efflux may have been in part the result of catchment morphology, which became narrower downstream and may be specific to the Stringer Creek Watershed. This morphology resulted in a downstream decrease in UAA and increase in slope (Table I), and lower SWC and groundwater table depth were observed downstream, which likely influenced the downstream decrease in efflux. However, catchments with different morphology may observe a different trend, and care should be taken when extrapolating the results of this study to catchments with different landscape structure.

The influence of catchment morphology on groundwater table dynamics and soil respiration was also evident when comparing sites at contrasting locations. Soil $\mathrm{CO}_{2}$ efflux and groundwater dynamics at T1-4 (upstream, TWI $=9.4$ ) and T6-4 (downstream, TWI = 8.5; Table I) are shown in Figure 9. At the beginning of June, the groundwater table was at or near the ground surface at both locations. However, the groundwater table was more persistent at T1-4, where soils remained saturated until the beginning of July, after which the groundwater table remained within $10 \mathrm{~cm}$ of the ground surface for the remainder of the measurement period (Figure 9). At this location, median SWC was $63 \%$ across the course of this study, confirming expectations of high wetness status in an area with relatively high UAA and gentle slopes (Table I). In contrast, the groundwater table quickly declined to $30 \mathrm{~cm}$ below the ground surface by the beginning of July at T6-4, and continued to decrease over the rest of the measurement period (Figure 9). 


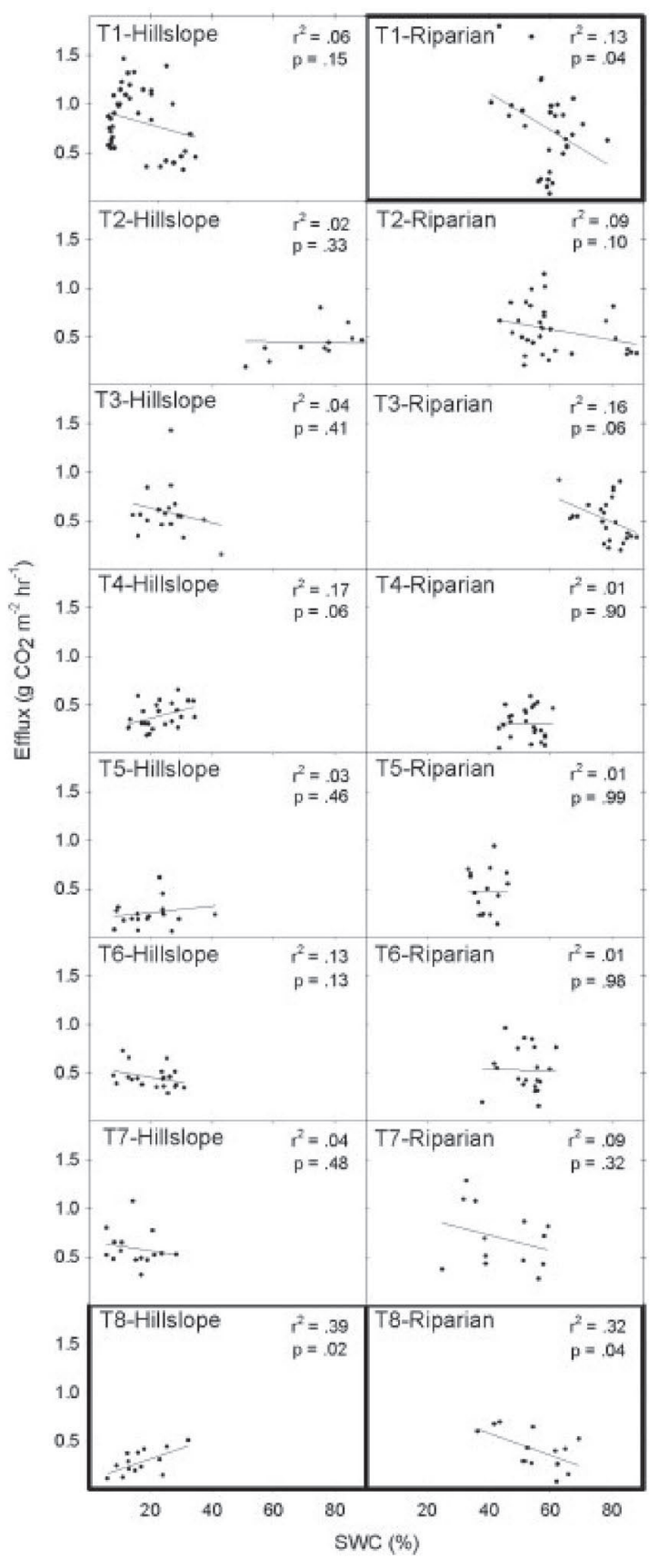

Figure 7. Bivariate plots of SWC and surface $\mathrm{CO}_{2}$ efflux at riparian and hillslope zones along each transect, collected from June 9 to $\mathrm{Au}-$ gust 31, 2005. Solid lines denote linear regression, and $p$-values are provided for at $\alpha=0.05$. Dark boxes indicate a statistically significant relationship.

At T6-4, UAA was less than half than that at T1-4, the slope was steeper (which resulted in a lower TWI than at T1-4), and SWC was lower (median of 53\%). As expected, cumulative efflux was much higher at T1-4 (1918 $\mathrm{g} \mathrm{CO}_{2} \mathrm{~m}^{-2}$ during the growing season compared to only $1025 \mathrm{~g} \mathrm{CO}_{2} \mathrm{~m}^{-2}$ during the growing season at T6-4). This contrast in efflux between areas with large differences in landscape structure highlights the need to examine catchment morphology and resulting groundwater table dynamics and soil wetness status when ex- amining soil respiration in complex landscapes.

The impact of variable SWC across the landscape on soil respiration is also apparent when examining soil gas diffusivity. In contrast to SWC, soil gas diffusivity increased downstream, but only in the riparian zones (Figures 3 and 6). We infer that significant differences in only riparian zone soil gas diffusivity were the result of a wider range of riparian SWC across the study period (35-85\% in the riparian zones versus 10 $40 \%$ in the hillslopes; Figure 3), as even small changes in SWC can significantly impact soil gas transport (Millington, 1959; Washington et al., 1994; Moldrup et al., 2000, 2001). This relationship between soil gas transport and SWC is supported by Risk et al. (2002), who observed differences in soil gas diffusivity of up to a factor of $10^{4}$ across a similar range of riparian SWC observed in the Stringer Creek Watershed. Thus, the large variability in riparian (but not hillslope) SWC and soil gas diffusivity was potentially controlled by groundwater table dynamics. Groundwater table development was not observed above the well completion depths of 1-2 $\mathrm{m}$ in the hillslopes, and SWC never exceeded $40 \%$ and varied by only $30 \%$ across all transects. This small range in hillslope SWC resulted in less significant differences in soil gas diffusivity between hillslopes. In contrast, the groundwater table was at or near the ground surface at many riparian wells at the beginning of June, but declined by $20-80 \mathrm{~cm}$ by the end of August. This wider range in riparian groundwater table depth over the course of this study explains the wider range of riparian SWC and significant differences in riparian soil gas diffusivity between transects. It is possible that in the upper-Stringer Creek Watershed, a shift from wet to dry soil wetness status is necessary for significant differences in soil gas diffusivity to occur. In the hillslopes, SWC was already low at the beginning of June (maximum of $40 \%$ ), and this "wet-dry" shift never occurred. In contrast, the SWC in the riparian zones was often over $60 \%$ at the beginning of June, but decreased to $\sim 40 \%$ at many locations by the end of August. A strong "wet-dry" shift occurred at many riparian locations, which resulted in large differences in SWC, and therefore soil gas diffusivity among riparian zones.

Aspect (east versus west) generally did not impact growing season soil respiration within or among riparian and hillslope zones in the upper-Stringer Creek Watershed (Figure 3). There were significant differences in soil temperature between transects (Figure 6); however, these occurred early in the growing season as a result of differences in snowpack persistence as well as the influence of the high specific heat of water in saturated areas (Pacific et al., 2008). Indeed, as all landscape positions became snowfree and SWC declined in many saturated areas, variability in soil temperature between east and west aspects was no longer statistically different (Figure 6). However, our results contrast with those of other studies of soil respiration in complex terrain. Kang et al. (2006) found higher soil temperatures on south- versus northfacing slopes in response to greater differences in incoming solar radiation between north and south aspects, 

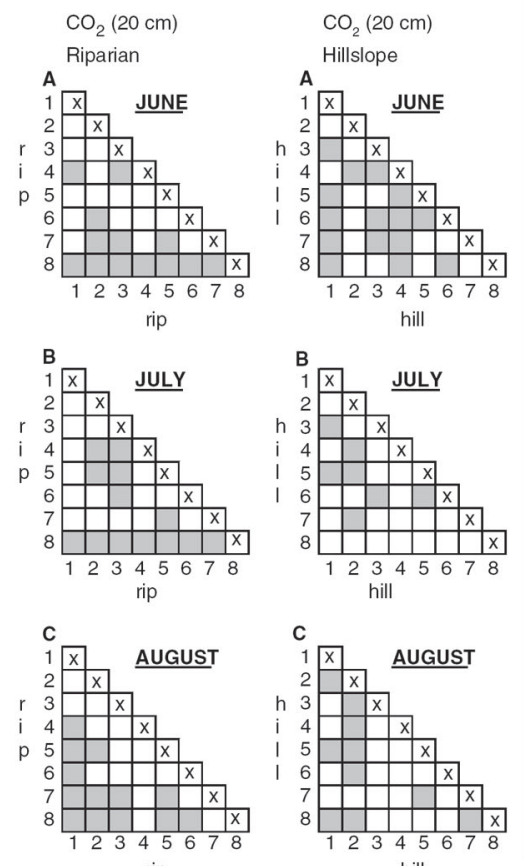

rip

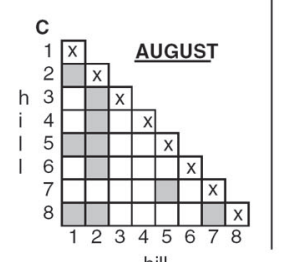

hill
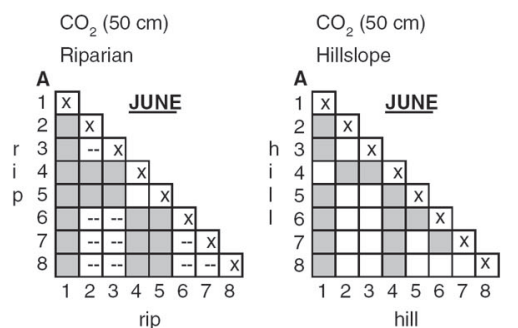

hill
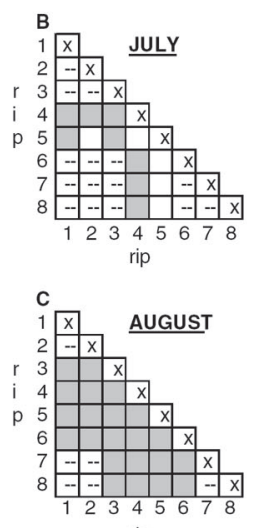

rip
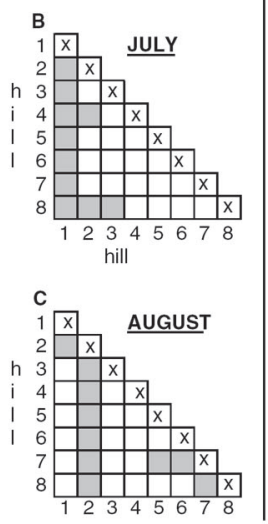

hill

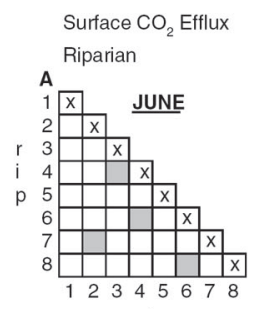

rip
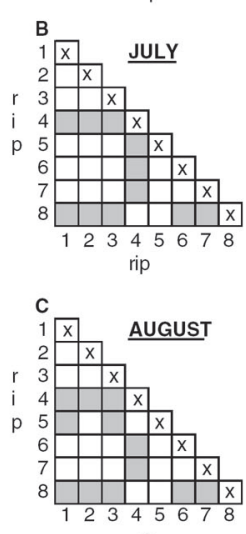

rip

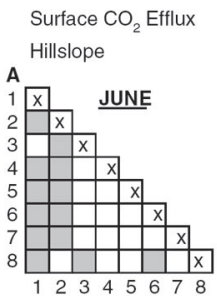

hill
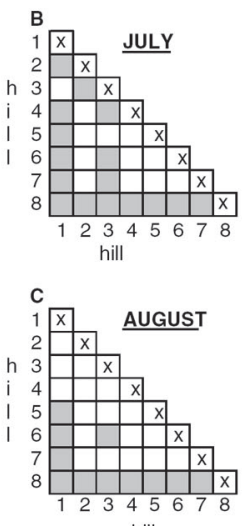

hill

Figure 8. Analysis of variance statistics $(\mathrm{a}=0.05)$ for transect-versus-transect comparisons of riparian and hillslope soil $\mathrm{CO}_{2}$ concentrations $(20$ and $50 \mathrm{~cm}$ ) and surface $\mathrm{CO}_{2}$ efflux during (A) June, (B) July, and (C) August 2005. Shaded boxes indicate significant differences. Dashed lines for $50 \mathrm{~cm}$ riparian soil $\mathrm{CO}_{2}$ concentrations indicate that concentrations were not measurable due to groundwater saturation. $n$ ranged from 24 for T7 versus T8 in June to 80 for T1 versus T2 in July.

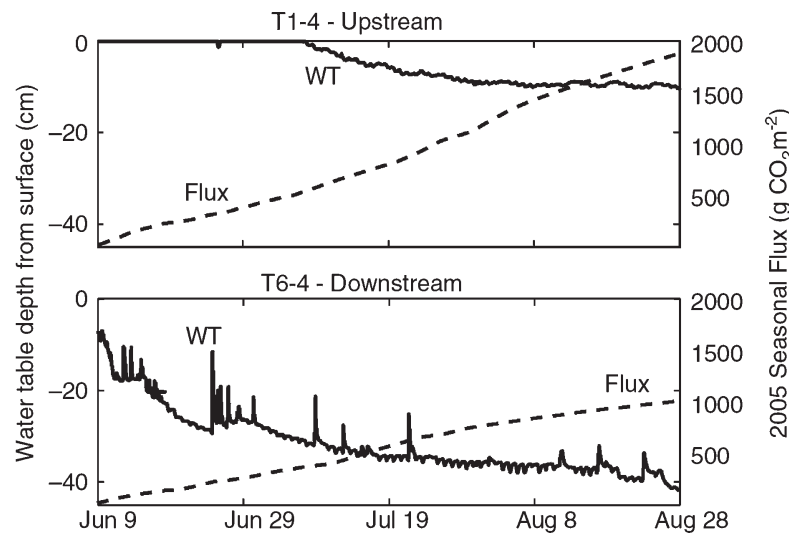

Figure 9. Groundwater table (WT) dynamics and cumulative surface $\mathrm{CO}_{2}$ efflux (Flux) at T1-4 and T6-4 from June 9 to August 31, 2005.

compared to west versus east in our study site. RiverosIregui and McGlynn (2009) found higher soil temperature on southeast versus northwest aspects in the same watershed as this study. However, their work collected measurements over much larger spatial extents (e.g. transects of hundreds of meters in length versus $\sim 50 \mathrm{~m}$ in our study), including high-elevation ridges. Thus the smaller spatial extent of our study may not have fully captured the effect of aspect on soil respiration.

\section{How does surface $\mathrm{CO}_{2}$ efflux differ between two hydro- logically distinct landscape positions: riparian (wet) and hillslope (dry) areas?}

We found heterogeneity in efflux between riparian and hillslope zones within each transect, although this heterogeneity did not become apparent until measurements

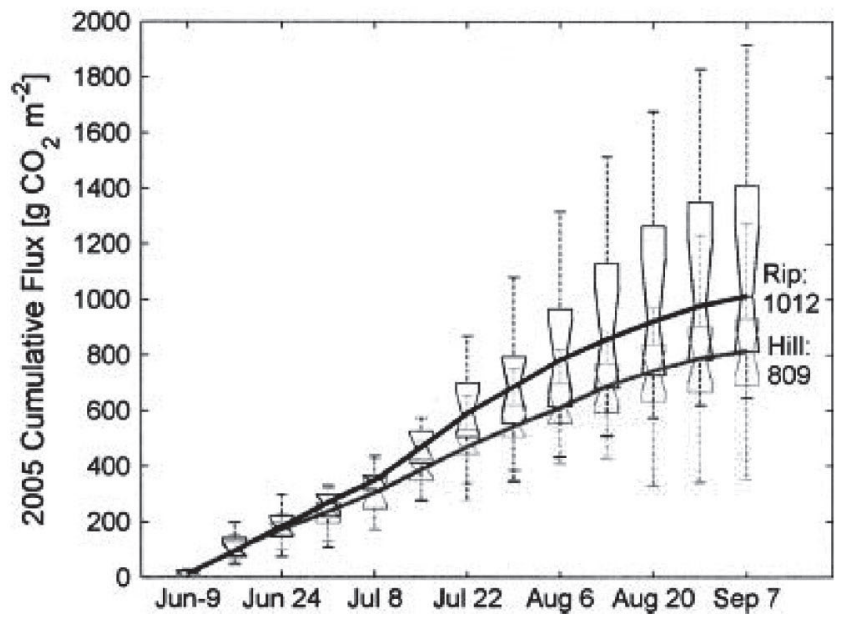

Figure 10. Box-plots of cumulative growing season efflux (June 9 to August 31, 2005) from all riparian and hillslope locations. In the riparian zones, cumulative efflux was $1012 \mathrm{~g} \mathrm{CO}_{2} \mathrm{~m}^{-2}$ during the 83-day growing season, whereas it was only $809 \mathrm{~g} \mathrm{CO}_{2} \mathrm{~m}^{-2}$ during the growing season in the hillslopes.

were integrated across the entire growing season. Monthly surface $\mathrm{CO}_{2}$ efflux was in general not significantly different between riparian and hillslope zones according to ANOVA results (Table II). This may be explained by the strong temporal heterogeneity in instantaneous efflux at monthly timescales, as well as the tradeoffs between the relative control of SWC on soil $\mathrm{CO}_{2}$ production and transport (at shorter timescales) across the landscape. An increase in SWC can lead to higher soil $\mathrm{CO}_{2}$ production (Davidson et al., 1998, 2000), but simultaneously reduce soil gas diffusivity (Millington, 1959; Washington et al., 1994; Moldrup et al., 2000, 2001). 


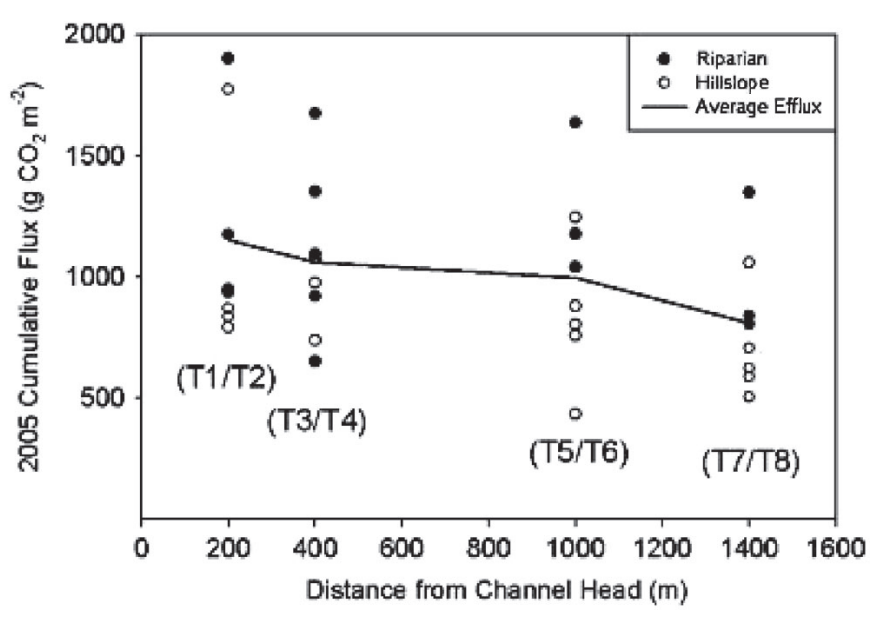

Figure 11. Cumulative growing season efflux (June 9 to August 31, 2005) from riparian and hillslope locations versus distance from channel head. Transects 1 and 2 (T1/T2) are the most upstream transects, whereas Transects 7 and 8 (T7/T8) are located furthest downstream.

At landscapes where SWC-mediated $\mathrm{CO}_{2}$ production and transport are spatially variable, efflux equifinality (i.e. comparable outcomes with different combinations of the variables) may occur at short timescales (Pacific et al., 2008). In the upper-Stringer Creek Watershed, riparian zone SWC was often in the intermediate range (defined as 40-60\% in the TCEF) (Figure 3), optimal for soil $\mathrm{CO}_{2}$ production (Davidson et al., 2000; Schwendenmann et al., 2003; Sjogersten et al., 2006). However, increased riparian SWC also decreased soil gas transport (Millington, 1959; Washington et al., 1994; Moldrup et al., 2000, 2001), and riparian soil gas diffusivity rates were nearly an order of magnitude lower than in the adjacent hillslopes (Figure 3). In contrast, low hillslope SWC (median values of $\sim 20 \%$, Figure 3 ) resulted in decreased soil $\mathrm{CO}_{2}$ production relative to the riparian zones, but higher soil gas transport. We suggest this tradeoff between the relative control of SWC on soil $\mathrm{CO}_{2}$ production and transport resulted in riparian and hillslope zone equifinality in surface $\mathrm{CO}_{2}$ efflux at monthly timescales.

However, higher riparian zone efflux $(p<0.01)$ becomes apparent when integrating to cumulative growing season efflux (June-August) (Figure 9). Cumulative efflux across the 83-day growing season was, on average, $25 \%$ higher in the riparian zones within each transect, suggesting increased riparian zone soil $\mathrm{CO}_{2}$ production in response to higher SWC and higher and more persistent groundwater table development. Soil temperature was not significantly different between riparian and hillslope positions (Table II, Figure 3) and likely had little control on the spatial variability of soil respiration within each transect, which is consistent with other investigations (Pinol et al., 1995; Xu and Qi, 2001; Scott-Denton et al., 2003). Our results illustrate that large variability in efflux can exist across the landscape when measurements are integrated over longer time periods (e.g. growing season), supporting the use of cumulative fluxes as a tool in multi-site, landscape- scale comparisons of soil respiration and other soil greenhouse gases (Pattey et al., 2007; Pacific et al., 2008; Riveros-Iregui et al., 2008; Merbold et al., 2009; RiverosIregui and McGlynn, 2009).

Differences in SOM across transects likely influenced the observed variability in riparian and hillslope soil respiration (Ostendorf, 1996; Ju and Chen, 2005; Sjogersten et al., 2006). To address the influence of SOM on the spatial variability of soil respiration, we examined molar soil $\mathrm{C}: \mathrm{N}$ ratios, which are often used as a predictor of decomposition rates (Enriquez et al., 1993; Gholz et al., 2000; Chapin et al., 2002). Lower soil C:N ratios are generally more optimal for microbial decomposition (Enriquez et al., 1993; Gholz et al., 2000), with optimal ratios between 10:1 and 12:1 (Pierzynski et al., 2000). Molar soil C:N ratios often approached this range in the riparian zones (Figure 2), and riparian $\mathrm{Cu}-$ mulative efflux across the 83-day growing season was much higher than from the adjacent hillslope zones, where molar soil C:N ratios were generally above 20:1 (Figure 2). These differences in molar soil C:N ratios may be due to differences in above- and below-ground vegetation litter (Raich and Tufekcioglu, 2000; Smith and Johnson, 2004; Kellman et al., 2007), as Riveros-Iregui and McGlynn (2009) found riparian vegetation had lower molar C:N ratios than hillslope vegetation in the same catchment. In addition, grassy riparian meadows have a higher allocation of photosynthate below the ground compared to the forested hillslopes (Raich and Tufekcioglu, 2000), which is often a large labile source of carbon for microbial activity (Baldocchi et al., 2006). At the catchment scale, Riveros-Iregui and McGlynn (2009) found root density to be correlated with landscape position; however, we did not find significant differences between riparian and hillslope positions. Groundwater table dynamics may have influenced riparian and hillslope SOM variability, as frequent saturation retards microbial decomposition (Schlesinger, 1997). For example, soil C:N ratios were generally lower (more optimal) in the riparian zone on upstream transects (Figure 2), and we hypothesize that higher and more persistent groundwater table development in the riparian zones on upstream transects (Table I) led to higher riparian SOM (McGlynn and McDonnell, 2003; Hill et al., 2004; Gurwick et al., 2008).

Although soil C:N ratios are often used to infer decomposition rates, we point out that litter carbon quality (labile versus recalcitrant) may be a better predictor of decomposition rates (Melillo et al., 1982) and should be accounted for in studies of the spatial variability of soil respiration. However, it was beyond the scope of this research to quantify the lability of soil $\mathrm{C}$ pools, and therefore molar soil C: $\mathrm{N}$ ratios were used to assess the influence of SOM on the spatial variability of soil respiration. Furthermore, it is possible that our measurements of $C$ concentrations at 20 and $50 \mathrm{~cm}$ characterized more recalcitrant soil $\mathrm{C}$ pools, and future soil respiration studies should account for the labile C pool in the upper soil horizons, which could potentially vary by vegetation type and slope position across the landscape. 
How can landscape metrics be used to explain dynamics between surface $\mathrm{CO}_{2}$ efflux and SWC or soil temperature across multiple riparian and hillslope positions?

Our results demonstrate that consistent relationships between instantaneous surface $\mathrm{CO}_{2}$ efflux and growing season soil temperature or SWC did not exist in the upper-Stringer Creek Watershed and suggest caution for transfer of such relationships across complex terrain. There were significant relationships between efflux and soil temperature or SWC across some transects $\left(\mathrm{m}^{2}\right.$ scale) (Figures 5 and 7); however, the relationships were very weak (low $r^{2}$ values), and one relationship could not be applied to all riparian and hillslope zones within and among transects. In fact, Riveros-Iregui and McGlynn (2009) found that across the entire upper-Stringer Creek Watershed $\left(\mathrm{km}^{2}\right.$ scale), efflux and soil temperature or SWC relationships were poor, and the only explanatory variable found for soil respiration was landscape morphology and structure. Quantification of relationships between efflux and soil temperature or SWC was based on instantaneous point measurements across a wide range of conditions in the upper-Stringer Creek Watershed. In contrast, landscape morphology and structure incorporates long-term hydrological dynamics, as wetter landscape positions often occur in areas with large UAA and gentle slopes (high TWI), and therefore may be a better predictor of soil respiration in complex landscapes than efflux and soil temperature or SWC relationships. The weakening of relationships between efflux and soil temperature or SWC as one moves from the small scale $\left(\sim \mathrm{m}^{2}\right)$ to the large scale $\left(\sim \mathrm{km}^{2}\right)$ demonstrates the role of multiple nested biophysical variables acting in space and time, which may result in confounding interactions between soil temperature, SWC, soil physical properties, and substrate availability, which are mediated by differences in landscape position. This weakening also reveals hierarchy in the biophysical controls of soil respiration across scales, and the implementation of such hierarchy into realistic process models capable of simulating and predicting soil respiration at multiple scales is simply necessary. Although there was not an overarching relationship between SWC and instantaneous surface $\mathrm{CO}_{2}$ efflux in this study location (Figure 4), temporal integration revealed emergent patterns in SWC-efflux relationships not captured by instantaneous measurements (Riveros-Iregui and McGlynn, 2009), in which higher cumulative growing season efflux was generally observed in wetter landscape positions.

The wide range of SWC and efflux (Figure 4) contributed to the lack of an overarching relationship between efflux and SWC or soil temperature. For example, groundwater saturation inhibited soil respiration at many riparian zone locations early in the growing season. However, efflux often increased by up to an order of magnitude at these locations as the groundwater table declined and SWC decreased (Pacific et al., 2008). Furthermore, in the hillslopes, T1-2 had unusually high efflux, likely in response to a fallen tree and related litterfall increase, which can stimulate soil respiration due to increases in above- and below-ground carbon availability, soil temperature, and SWC. When this nest was removed from data analysis (denoted by dashed regression line in Figure 4), the relationships became weaker, and in the case of surface $\mathrm{CO}_{2}$ efflux versus SWC, they were not significantly different. Our results demonstrate the importance of measurement collection across wide ranges of landscape positions, and exercising caution when applying empirical relations (e.g. soil temperature-SWC-efflux) in models of soil respiration across large spatial scales.

\section{Implications for up-scaling of soil respiration measurements}

In order to gain understanding of soil respiration variability from the point to the watershed or ecosystem scale, it is necessary to collect and analyze measurements over a wide range of landscape positions, spatial and temporal scales, and across wide ranges of biophysical gradients. As such data collection is demanding and often unfeasible, studies of landscape-scale soil respiration must employ techniques and experimental designs that bridge the gap between point and landscape scale measurements. In tandem with field observations, terrain analysis and landscape metrics (e.g. UAA and slope estimation) and remote sensing techniques are useful tools to scale point soil respiration measurements to larger areas, and to bring biophysical relationships found at smaller scales into larger, geomorphic contexts.

Soil respiration and respiration-driving variables differed across landscape positions with large differences in UAA, slope, TWI, and groundwater table dynamics in the upper-Stringer Creek Watershed. In the riparian zones, soil $\mathrm{CO}_{2}$ concentrations ranged broadly (often by over 20000 ppm, Figure 4), and cumulative efflux during the growing season was generally higher and had a wider range than the adjacent hillslopes along each transect (Figure 10). These trends were potentially in response to the wider range of riparian SWC $(\sim 35-85 \%$, Figure 3), more variable groundwater table depths, and more narrow (optimal) molar soil C:N ratios (Figure 2). This was in contrast to the hillslopes, where a smaller range in cumulative efflux was observed, and the range of soil $\mathrm{CO}_{2}$ concentrations did not exceed $5000 \mathrm{ppm}$ (Figure 3). At these hillslope locations, groundwater table development was not observed, the range of SWC was low (10-40\%, Figure 3), and molar soil C:N ratios were higher and less optimal (Figure 2). Furthermore, higher cumulative efflux was found on upstream transects (Figure 11), where TWI values were larger in response to higher UAA and gentler slopes (Table I), and the groundwater table was relatively high and more persistent. The lowest cumulative efflux was measured on downstream transects where low UAA and steep slopes resulted in a low TWI, and deeper groundwater tables in the riparian zones were observed. These findings highlight the potential of landscape context for interpreting point and plot scale measurements of soil respiration. This concept is widely used in hydrological modeling, in which landscape position similarity is 
often related to hydrological behavior similarity (McGlynn et al., 2004; Beighley et al., 2005; Seibert and McGlynn, 2005). Our findings indicate that landscape position may also be related to carbon dynamics, or "carbon context," to interpret and extrapolate point-scale measurements of soil respiration to larger landscapes. Therefore, landscape analysis can provide a way forward in up-scaling soil respiration measurements and be useful when modeling soil respiration to reduce potentially large uncertainty in scaling point measurements to landscape and regional scales.

\section{Conclusions}

Measurements of growing season (June-August) SWC, soil temperature, groundwater dynamics, soil $\mathrm{C}$ and $\mathrm{N}$ concentrations, soil $\mathrm{CO}_{2}$ concentrations, and surface $\mathrm{CO}_{2}$ efflux across eight topographically distinct riparian-hillslope transitions within the upper-Stringer Creek Watershed demonstrated that:

1. Landscape attributes such as slope and UAA impacted groundwater table dynamics and affected soil respiration-driving variables such as SWC and SOM, and therefore must be accounted for when investigating landscape-level dynamics of biogeochemical fluxes.

2. Instantaneous soil surface $\mathrm{CO}_{2}$ efflux was not significantly different both within and among riparian and hillslope zones at monthly timescales according to ANOVA analysis. This was likely the result of different mechanistic controls on $\mathrm{CO}_{2}$ production and transport and efflux equifinality at short timescales.

3. Cumulative growing season efflux was $25 \%$ higher in the riparian zones than the adjacent hillslopes, which demonstrates that large differences in soil respiration existed between riparian and hillslope zones over longer timescales, and highlights the importance of temporal integration in comparisons of surface $\mathrm{CO}_{2}$ efflux across landscapes.

4. Landscape position can be related to both soil water and carbon dynamics and may be a valid approach to interpret and extrapolate point/plot scale measurements of soil respiration to larger landscapes.

Our findings indicate that landscape position and contextual variables such as slope and UAA can influence soil respiration. Differential controls of respiration drivers such as SWC, SOM availability, groundwater table dynamics, and soil gas diffusivity may lead to organized heterogeneity in cumulative surface $\mathrm{CO}_{2}$ efflux as a function of landscape position. Our results highlight the need for further investigations of the spatial variability of soil respiration in complex terrain across a range of biophysical gradients, groundwater dynamics, and landscape positions in order to elucidate the primary controls of respiration heterogeneity across the landscape.
Acknowledgments - We gratefully acknowledge field assistance from Kelsey Jencso, Becca McNamara, Kelley Conde, and Austin Allen. We thank the Tenderfoot Creek Experimental Forest and the USDA, Forest Service, Rocky Mountain Research Station, especially Ward McCaughey, for logistical support and research site access. This work was funded by the NSF Integrated Carbon Cycle Research Program (ICCR, NSF Grant EAR0404130, EAR0403924, and EAR0403906) and fellowships awarded to V. J. Pacific from the Big Sky Institute NSF GK-12 program, Inland Northwest Research Alliance (INRA), and the Montana Water Center Student Research Grant Program. D. A. Riveros-Iregui acknowledges support from the 2007 American Geophysical Union Horton Research Grant, an NSF Doctoral Dissertation Improvement Grant (DEB-0807272), and the USGS 104b Grant Program, administered by the Montana Water Center. Airborne laser mapping was provided by the NSF-supported National Center for Airborne Laser Mapping (NCALM) at the University of California, Berkeley.

\section{References}

Anderson MG, Burt TP. 1978. Role of topography in controlling throughflow generation. Earth Surface Processes and Landforms 3: 331-344.

Andrews JA, Schlesinger WH. 2001. Soil CO2 dynamics, acidification, and chemical weathering in a temperate forest with experimental CO2 enrichment. Global Biogeochemical Cycles 15: 149-162.

Baldocchi D, Tang J, Xu L. 2006. How switches and lags in biophysical regulators affect spatial-temporal variation of soil respiration in an oakgrass savanna. Journal of Geophysical Research 111: G02008. DOI: 10.1029/2005JG000063.

Beighley RE, Dunne T, Melack JM. 2005. Understanding and modeling basin hydrology: interpreting the hydrogeological signature. Hydrological Processes 19: 1333-1353.

Beven KJ, Kirkby MJ. 1979. A physically-based variable contributing area model of basin hydrology. Hydrologic Science Bulletin 24: 43-69.

Bonell M. 1998. Selected challenges in runoff generation research in forests from the hillslope to headwater drainage basic scale. Journal of the American Water Resources Association 34: 765-785.

Chapin FS, Matson PA, Mooney HA. 2002. Principles of Terrestrial Ecosystem Ecology. Springer: New York; 436.

Conant RT, Klopatek JM, Malin RC, Klopatek CC. 1998. Carbon pools and fluxes along an environmental gradient in northern Arizona. Biogeochemistry 43: 43-61.

Cosanday AC, Maitre V, Guenat C. 2003. Temporal denitrification patterns in different horizons of two riparian soils. European Journal of Soil Science 54: 25-38.

Davidson EA, Belk E, Boone RD. 1998. Soil water content and temperature as independent or confounded factors controlling soil respiration in a temperate mixed hardwood forest. Global Change Biology 4: 217-227.

Davidson EA, Verchot LV, Cattanio JH, Ackerman IL, Carvalho JEM. 2000. Effects of soil water content on soil respiration in forests and cattle pastures of eastern Amazonia. Biogeochemistry 48: 53-69.

Dunne T, Black RD. 1970. Partial area contributions to storm runoff in a small New England watershed. Water Resources Research 6: 1296-1311.

Enriquez S, Duarte CM, Sand-Jensen K. 1993. Patterns in decomposition rates among photosynthetic organisms: the importance of detritus C :N: P content. Oecologia 94: 457-451. 
Epron D, Nouvellon Y, Roupsard O, Mouvondy W, Mabiala A, Saint- Andre L, Joffre R, Jourdan C, Bonnefond J, Berbigier P, Hamel O. 2004. Spatial and temporal variations of soil respiration in a eucalyptus plantation in Congo. Forest Ecology and Management 202: 149-160.

Fang C, Moncrieff JB. 1999. A model for soil CO2 production and transport 1: model development. Agricultural and Forest Meteorology 95: 225-236.

Fang C, Moncrieff JB. 2001. The dependence of soil CO2 efflux on temperature. Soil Biology \& Biochemistry 33: 155-165.

Farnes PE, Shearer RC, McCaughey WW, Hanson KJ. 1995. Comparisons of Hydrology, Geology and Physical Characteristics between Tenderfoot Creek Experimental Forest (East Side) Montana, and Coram Experimental Forest (West Side) Montana. Final Report RJVA-INT- 92734. USDA Forest Service, Intermountain Research Station, Forestry Sciences Laboratory: Bozeman, MT; 19.

Gholz HL, Wedin DA, Smitherman SM, Harmon ME, Parton WJ. 2000. Long-term dynamics of pine and hardwood litter in contrasting environments: Toward a global model of decomposition. Global Change Biology 6: 751-765.

Gulledge J, Schimel JP. 2000. Controls on soil carbon dioxide and methane fluxes in a variety of taiga forest stands in interior Alaska. Ecosystems 3: 269-282.

Gurwick NP, Groffman PM, Yavitt JB, Gold AJ, Blazejewski G, Stolt M. 2008. Microbially available carbon in buried riparian soils in a glaciated landscape. Soil Biology \& Biochemistry 40: 85-96.

Happell JD, Chanton JP. 1993. Carbon remineralization in a north Florida swamp forest: effects of water level on the pathways and rates of soil organic matter decomposition. Global Biogeochemical Cycles 7: 475-490.

Hill AR. 1996. Nitrate removal in stream riparian zones. Journal of Environmental Quality 25: 743-755.

Hill AR, Cardaci M. 2004. Denitrification and organic carbon availability in riparian wetland soils and subsurface sediments. Soil Science Society of America Journal 68: 320-325.

Hill AR, Vidon PGF, Langat J. 2004. Denitrification potential in relation to lithology in five headwater riparian zones. Journal of Environmental Quality 33: 911-919.

Holdorf HD. 1981. Soil Resource Inventory, Lewis and Clark National Forest-Interim In-Service Report. On file with the Lewis and Clark National Forest, Forest Supervisor's Office, Great Falls, MT.

Jencso KJ, McGlynn BL, Gooseff MN, Bencala KE, Wondzell SM. 2010. Hillslope hydrologic connectivity controls riparian groundwater turnover: Implications of catchment structure for riparian buffering and stream water sources. Water Resources Research. In press.

Jencso KJ, McGlynn BL, Gooseff MN, Wondzell SM, Bencala KE. 2009. Hydrologic connectivity between landscapes and streams: transferring reach and plot scale understanding to the catchment scale. Water Resources Research 45: W04428. DOI: 10.1029/2008WR007225.

Ju W, Chen JM. 2005. Distribution of soil carbon stocks in Canada's forests and wetlands simulated based on drainage class, topography and remotely sensed vegetation parameters. Hydrological Processes 19: 77-94.

Kang S, Lee D, Lee J, Running S. 2006. Topographic and climatic controls on soil environments and net primary production in a rugged temperate hardwood forest in Korea. Ecology Research 21: 64-74.

Kellman L, Beltrami H, Risk D. 2007. Changes in seasonal soil respiration with pasture conversion to forest in Atlantic Canada. Biogeochemistry 82: 101-109. DOI: 10.1007/ s10533-006-9056-0.
Liu HS, Li FM. 2005. Root respiration, photosynthesis and grain yield of two spring wheat in response to soil drying. Plant Growth Regulation 46: 233-240.

McCarthy DR, Brown KJ. 2006. Soil respiration responses to topography, canopy cover, and prescribed burning in an oak-hickory forest in southeastern Ohio. Forest Ecology and Management 237: 94-102.

McGlynn BL, McDonnell JJ. 2003. Role of discrete landscape elements in controlling catchment dissolved organic carbon dynamics. Water Resources Research 39: 1090. DOI: 10.1029/2002WR001525.

McGlynn BL, McDonnell JJ, Seibert J, Kendall C. 2004. Scale effects on headwater catchment runoff timing, flow sources, and groundwaterstreamflow relations. Water Resources Research 40: W07504. DOI: 10.1029/2003WR002494.

McGlynn BL, Seibert J. 2003. Distributed assessment of contributing area and riparian buffering along stream networks. Water Resources Research 39: 1082. DOI: 10.1029/2002WR001521.

Melillo JM, Aber JD, Muratore JF. 1982. Nitrogen and lignin control of hardwood leaf litter decomposition dynamics. Ecology 63: 621-626.

Merbold L, Kutsch WL, Corradi C, Kolle O, Rebmann C, Stoy PC, Zimovs SA, Schulze ED. 2009. Atrificial drainage and associated carbon fluxes $(\mathrm{CO} 2 / \mathrm{CH} 4)$ in a tundra ecosystem. Global Change Biology 15: 2599-2614. DOI: 10.1111/j.1365- 2486.2009.01962.x.

Merot P, Ezzahar B, Walter C, Aurousseau P. 1995. Mapping waterlogging of soils using digital terrain models. Hydrological Processes 9: 27-34.

Millington RJ. 1959. Gas diffusion in porous media. Science 130: 100-102.

Mincemoyer SA, Birdsall JL. 2006. Vascular flora of the Tenderfoot Creek Experimental Forest, Little Belt Mountains, Montana. Madrono 53: 211-222.

Moldrup P, Olsen T, Komatsu T, Schjønning P, Rolston DE. 2001. Tortuosity, diffusivity, and permeability in the soil liquid and gaseous phases. Soil Science Society of America Journal 65: 613-623.

Moldrup P, Olsen T, Schjønning P, Yamaguchi T, Rolston DE. 2000. Predicting the gas diffusion coefficient in undisturbed soil from soil water characteristics. Soil Science Society of America Journal 64: 94-100.

Mourier B, Walter C, Merot P. 2008. Soil distribution in valleys according to stream order. Catena 72: 395-404.

Ostendorf B. 1996. Modeling the influence of hydrological processes on spatial and temporal patterns in $\mathrm{CO} 2$ soil efflux from an arctic tundra catchment. Arctic and Alpine Research 28: 318-327.

Pacific VJ, Jencso KJ, McGlynn BL. 2010. Variable flushing mechanisms and landscape structure control stream DOC export during snowmelt in a set of nested catchments. Biogeochemistry 99: 193-211. DOI: 10.1007/s10533-009-9401-1.

Pacific VJ, McGlynn BL, Riveros-Iregui DA, Epstein HE, Welsch DL. 2009. Differential soil respiration responses to changing hydrologic regimes. Water Resources Research 45: W07201. DOI: 10.1029/2009WR007721.

Pacific VJ, McGlynn BL, Riveros-Iregui DA, Welsch DL, Epstein HE. 2008. Variability in soil respiration across riparian-hillslope transitions. Biogeochemistry 91: 51-70. DOI: 10.1007/s10533-008-9258-8.

Parkin TB, Kasper TC, Senwo Z, Prueger JH, Hatfield JL. 2005. Relationship of soil respiration to crop and landscape in the Walnut Creek Watershed. Journal of Meteorology 6: 812-824.

Pattey E, Edwards GC, Desjardins RL, Pennock DJ, Smith W, Grant B, MacPherson JI. 2007. Tools for quantifying N2O 
emissions from agroecosystems. Agricultural and Forest Meteorology 142: 103-119.

Phillips DH, Fossa JE, Stilesa CA, Trettinb CC, Luxmoore RJ. 2001. Soil-landscape relationships at the lower reaches of a watershed at Bear Creek near Oak Ridge, Tennessee. Catena 44: 205-222.

Pierzynski GM, Sims JT, Vance GF (eds). 2000. Soils and Environmental Quality. CRC Press: New York; 480.

Pinol J, Alcaniz JM, Roda R. 1995. Carbon dioxide efflux and pCO2 in soils of three Quercus ilex montane forests. Biogeochemistry 30: 191-215.

Raich JW, Potter CS, Bhagawati D. 2002. Interannual variability in global soil respiration, 1980-1994. Global Change Biology 8: 800-812.

Raich JW, Schlesinger WH. 1992. The global carbon dioxide flux in soil respiration and its relationship to vegetation and climate. Tellus 44B: 81-99.

Raich JW, Tufekcioglu A. 2000. Vegetation and soil respiration: correlations and controls. Biogeochemistry 48: 71-90.

Raymment MB, Jarvis PG. 2000. Temporal and spatial variation of soil CO2 efflux in a Canadian boreal forest. Soil Biology E Biochemistry 32: 35-45.

Risch AC, Frank DA. 2007. Effects on increased soil water availability on grassland ecosystem carbon dioxide fluxes. Biogeochemistry 86: 91-103.

Risk D, Kellman L, Beltrami H. 2002. Soil CO2 production and surface flux at four climate observatories in eastern Canada. Global Biogeochemical Cycles 16: 69-1-69-11. DOI: 10.1029/2001GB001831.

Riveros-Iregui DA, Emanuel RE, Muth DJ, McGlynn BL, Epstein HE, Welsch DL, Pacific VJ, Wraith JM. 2007. Diurnal hysteresis between soil temperature and soil CO2 is controlled by soil water content. Geophysical Research Letters 34: L17404. DOI: 10.1029/2007GL030938.

Riveros-Iregui DA, McGlynn BL. 2009. Landscape structure controls soil CO2 efflux variability in complex terrain: scaling from point observations to watershed-scale fluxes. Journal of Geophysical Research-Biogeosciences 114: G02010. DOI: 10.1029/2008JG000885.

Riveros-Iregui DA, McGlynn BL, Epstein HE, Welsch DL. 2008. Interpretation and evaluation of combined measurement techniques for soil CO2 efflux: discrete surface chambers and continuous soil CO2 concentration probes. Journal of Geophysical Research-Biogeosciences 113: G04027. DOI: 10.1029/2008JG000811.

Robinson DA, Jones SB, Wraith JM, Or D, Friedman SP. 2003. A review of advances in dielectric and electrical conductivity measurements in soils using time domain reflectometry. Vadose Zone Journal 2: 444-475.

Schimel D, Kittel TGF, Running S, Monson R, Turnipseed A, Anderson D. 2002. Carbon sequestration studied in western U.S. mountains. Eos Transactions-American Geophysical Union 83: 445-456.

Schlesinger WH. 1997. Biogeochemistry: An Analysis of Global Change. Academic Press: San Diego, CA; 588.

Schuur EAG, Trumbore SE. 2006. Partitioning sources of soil respiration in boreal black spruce forest using radiocarbon. Global Change Biology 12: 165-176.

Schwendenmann L, Veldkamp E, Brenes T, O’Brien JJ, Mackensen J. 2003. Spatial and temporal variation in soil CO2 efflux in an oldgrowth neotropical rain forest, La Selva, Costa Rica. Biogeochemistry 64: 111-128.

Scott-Denton LE, Rosenstiel TN, Monson RK. 2006. Differential controls by climate and substrate over the heterotrophic and rhizospheric components of soil respiration. Global Change Biology 12: 205-216.

Scott-Denton LE, Sparks KL, Monson RK. 2003. Spatial and temporal controls of soil respiration rate in a high-elevation, subalpine forest. Soil Biology $\mathcal{E}$ Biochemistry 35: 525-534.

Seibert J, McGlynn BL. 2005. Landscape element contributions to storm runoff. Encyclopedia of Hydrological Sciences. Wiley: Hoboken, NJ, USA.

Seibert J, McGlynn BL. 2007. A new triangular multiple flowdirection algorithm for computing upslope areas from gridded digital elevation models. Water Resources Research 43: W04501. DOI: 10.1029/2006WR005128.

Sjogersten S, van der Wal R, Woodin SJ. 2006. Small-scale hydrological variation determines landscape CO2 fluxes in the high Arctic. Biogeochemistry 80: 205-216.

Smith DL, Johnson L. 2004. Vegetation-mediated changes in microclimate reduce soil respiration as woodlands expand into grasslands. Ecology 85: 3348-3361.

Sotta ED, Veldkamp E, Guinaraes BR, Paixao RK, Ruivo MLP, Almeida SS. 2006. Landscape and climatic controls on spatial and temporal variation in soil CO2 efflux in an Eastern Amazonian Rainforest, Caxiuana, Brazil. Forest Ecology and Management 237: 57-64.

Sotta ED, Veldkamp E, Schwendenmann L, Guimaraes BR, Paixao RK, Ruivo MP, DaCosta AC, Meirs P. 2007. Effects of an induced drought on soil carbon dioxide (CO2) efflux and soil $\mathrm{CO} 2$ production in an Eastern Amazonian rainforest, Brazil. Global Change Biology 13: 1-12. DOI: 10.1111/j.1365-2486.2007.01416.x.

Tang J, Baldocchi DD. 2005. Spatial-temporal variation in soil respiration in an oak-grass savanna ecosystem in California and its partitioning into autotrophic and heterotrophic components. Biogeochemistry 73: 183-207.

Washington JW, Rose AW, Ciolkosz EJ, Dobos RR. 1994. Gaseous diffusion and permeability in four soil profiles in central Pennsylvania. Soil Science 157: 65-76.

Webster KL, Creed IF, Bourbonniere RA, Beall FD. 2008. Controls on the heterogeneity of soil respiration in a tolerant hardwood forest. Journal of Geophysical Research-Biogeosciences 113: G03040. DOI: 10.1029/2008JG000706.

Welsch DL, Hornberger GM. 2004. Spatial and temporal simulation of soil CO2 concentrations in a small forested catchment in Virginia. Biogeochemistry 71: 415-436.

Xu M, Qi Y. 2001. Soil-surface CO2 efflux and its spatial and temporal variations in a young ponderosa pine plantation in northern California. Global Change Biology 7: 667-677.

Xu W, Wan S. 2008. Water- and plant-mediated response of soil respiration to topography, fire, and nitrogen fertilization in semiarid grassland in northern China. Soil Biology $\mathcal{E}$ Biochemistry 40: 679-687.

Yuste JC, Baldocchi DD, Gershenson A, Goldstein A, Mission L, Wong S. 2007. Microbial soil respiration and its dependency on carbon inputs, soil temperature and moisture. Global Change Biology 13: 1-18. DOI: 10.1111/j.1365-2486.2007.01415.x. 